\title{
Long-term fish community response to a reach-scale stream restoration
}

\author{
Patrick D. Shirev $^{1,2}, \underline{\text { Michael A. Brueseke }}^{1}$, $\underline{\text { Jillian B. Kenny }}^{1,3}$ and Gary A. Lamberti $^{1}$
}

\begin{abstract}
At a global scale, aquatic ecosystems are being altered by human activities at a greater rate than at any other time in history. In recent years, grassroots efforts have generated interest in the restoration of degraded or destroyed aquatic habitats, especially small wetlands and streams where such projects are feasible with local resources. We present ecological management lessons learned from 17 years of monitoring the fish community response to the channel relocation and reach-level restoration of Juday Creek, a 3rdorder tributary of the St. Joseph River in Indiana, USA. The project was designed to increase habitat complexity, reverse the effects of accumulated fine sediment ( $<2 \mathrm{~mm}$ diameter), and mitigate for the impacts of a new golf course development. The 1997 restoration consisted of new channel construction within two reaches of a 1.2-km section of Juday Creek that also contained two control reaches. A primary social goal of the golf course development and stream restoration was to avoid harm to the non-native brown trout fishery, as symbolic of community concerns for the watershed. Our long-term monitoring effort revealed that, although fine sediment increased over time in the restored reaches, habitat conditions have promoted the resurgence of native fish species. Since restoration, the fish assemblage has shifted from non-native Salmonidae (brown trout, rainbow trout) to native Centrarchidae (rock bass, largemouth bass, smallmouth bass). In addition, native, nongame species have remained stable or have increased in population abundance (e.g., Johnny darter, mottled sculpin). The results of this study demonstrate the value of learning from a restoration project to adjust management decisions that enhance environmental quality.
\end{abstract}

Key Words: conservation; fisheries; long-term monitoring; restoration planning; stream ecology

\section{INTRODUCTION}

At a global scale, aquatic ecosystems are being altered by human activities at a greater rate than at any other time in history (Millennium Ecosystem Assessment 2005). Rivers and streams have served as the lifeblood of transportation, commerce, and industry, and have been subjected to a variety of human impacts, both direct (e.g., pollution, sewage, impoundment, channelization, introduced species) and indirect (e.g., riparian modification, wetland loss through draining, watershed land use change, fine sediment runoff) (Stanford et al. 1996, Paul and Meyer 2001, Benidickson 2007). These impacts have cumulatively degraded both water quality for human use and stream habitat for aquatic biota, thereby reducing ecosystem services (Palmer et al. 2007). As a result, actions such as restoration have been used in attempts to reverse loss of ecosystem services (Wohl et al. 2005). Restoration is defined by the Society for Ecological Restoration (2016) as assisting the recovery of an ecosystem that has been degraded, damaged, or destroyed. Stream restoration can lessen the human impact if it recoups habitat losses and reverses trends of declining water quality and quantity (Bernhardt et al. 2005). Ecosystem restoration can improve land and water productivity, enhance conservation, recover rare and endangered species, and restore ecosystem function (Society for Ecological Restoration 2016).

In recent years, grassroots efforts have generated interest in the restoration of degraded or destroyed aquatic habitats, from small streams and wetlands, where such projects are feasible with local resources, to large-scale efforts in river systems and drainage basins (e.g., the Laurentian Great Lakes Restoration Initiative, dam removal on rivers). While the volume of literature addressing stream and river restoration has increased markedly over the last two decades (e.g., Jansson et al. 2005, Palmer et al. 2005, Nilsson et al. 2007), the efficacy of restoring stream ecosystems as evaluated by monitoring has lagged restoration actions (Moerke and Lamberti 2003, Palmer 2009). One challenge that limits such analysis is that pre-existing conditions are not well documented for many manipulative projects, even those for strictly research purposes (Benke 1990, Wissmar and Beschta 1998). Even if a historic ecological state can be identified for a given stream, an effort to restore to that state may not be possible or desirable (Nilsson et al. 2007). In addition, reach-scale restoration efforts in streams are likely to be ineffective unless watershed issues that are contributing to degraded habitat are also addressed (Kauffman et al. 1997, Roni et al. 2008, Palmer et al. 2010, Violin et al. 2011). Finally, only about $10 \%$ of stream and river restoration projects are assessed or monitored to determine effectiveness and inform future restoration projects in achieving intended goals (Bernhardt et al. 2005). This gap could be due to (1) a lack of funding or expertise to monitor restorations, (2) the desire of scientists to move on to other research projects, or (3) the projects being labeled a success or failure before a long-term evaluation is performed (Bash and Ryan 2002, Reeve et al. 2006, Klein et al. 2007).

We use the case study of a channel relocation and reach-level restoration of Juday Creek in St. Joseph County, Indiana, USA to evaluate the outcome of the restoration for habitat conditions and fish populations. The goals of the Juday Creek channel relocation and reach restoration relative to the fish community were to (1) create a self-maintaining stream channel, (2) increase stream habitat diversity (to increase fish abundance and biomass), and (3) enhance biodiversity of fishes while also perpetuating an introduced cool-water fishery consisting of brown trout (Salmo trutta) and rainbow trout (Oncorhynchus mykiss). Previous publications on the Juday Creek restoration project at the Notre Dame Warren Golf Course (a 1.2-km segment in the southeast corner of Township 38N R3E) reported monitoring results for up 
Table 1. Design and outcome of the restoration project constructed by relocating two reaches of Juday Creek at the Warren Golf Course at the University of Notre Dame, Indiana.

\begin{tabular}{|c|c|c|c|}
\hline Habitat feature & Change in feature & Described goal & Outcome since restoration \\
\hline Stream length & $20 \%$ increase & Increase total length of the stream & Stream length has not changed since restoration \\
\hline Stream canopy & $20 \%$ initial increase & $\begin{array}{l}\text { Eventual increase of stream canopy cover (10-15 } \\
\text { years) of } 67 \%\end{array}$ & Canopy cover has increased (Table 3 ) \\
\hline Pools & $6 \mathrm{x}$ increase & 24 pools constructed versus 4 previous pools & $\begin{array}{l}\text { Some pools have filled with sediment; } 9 \text { large pools } \\
\text { remain in restored reach (2011) }\end{array}$ \\
\hline Logs & $7 \mathrm{x}$ increase & $\begin{array}{l}70 \text { logs used in the stream versus } 10 \text { existing log } \\
\text { jams before construction }\end{array}$ & $\begin{array}{l}\text { Some logs have been covered by fine sediment; } \\
\text { large woody debris has declined in restored reaches } \\
\text { over time (Table } 3 \text { ) }\end{array}$ \\
\hline Boulders & 60x increase & 360 boulders placed in the stream versus 6 present & No change \\
\hline Spawning areas & 24 constructed & $\begin{array}{l}\text { Provide spawning habitat, particularly for brown } \\
\text { trout }\end{array}$ & $\begin{array}{l}\text { Brown trout redds noticed for } 3 \text { years after } \\
\text { construction (Moerke and Lamberti 2003) }\end{array}$ \\
\hline Gravel substrate & $35 \mathrm{x}$ increase & $\begin{array}{l}671 \mathrm{~m}(2200 \mathrm{ft}) \text { of construction versus } 18 \mathrm{~m}(60 \\
\text { feet) }\end{array}$ & See Table 2 on fine sediment in riffle habitat \\
\hline Vegetation buffer & $20 \mathrm{~m}$ wide & Both banks of the relocated channels & Vegetation buffer has been maintained \\
\hline Sediment trap & $\begin{array}{l}\text { Installed above } \\
\text { restored reaches }\end{array}$ & $\begin{array}{l}\text { Reduce downstream deposition of sediment in } \\
\text { restored reaches, conducting periodic maintenance } \\
\text { as needed }\end{array}$ & Sediment trap dredged in 1999, 2001, 2003, 2013 \\
\hline Stream banks & Bank stabilization & $\begin{array}{l}\text { Coconut matting installed over } 800 \mathrm{~m} \text { of relocated } \\
\text { channel to protect plants }\end{array}$ & Coconut matting degraded \\
\hline Plastic netting & Retain rocks & Retain substrate until channel stabilizes & Plastic netting did not photo-degrade \\
\hline
\end{tabular}

to five years after project completion (i.e., 1997-2002) (Latimore 2000, Moerke and Lamberti 2003, 2004, Moerke et al. 2004, Gerard 2005). We monitored the restoration site (1) as a requirement of a permit from the U.S. Army Corps of Engineers, (2) because a lack of budgetary allocations constrained the environmental engineering company from conducting monitoring, and (3) to assess the efficacy of stream habitat restoration involving channel relocation. Variables monitored for five years (1997-2002) included fish, macroinvertebrates, periphyton, instream sediment, water temperature, conductivity, discharge, stream habitat, and canopy cover (Moerke et al. 2004). To document the long-term fish community response to restoration, we continued to monitor the fish community for an additional 11 years beyond the original permit requirement (i.e., 2003-2013). Although we resurveyed habitat features in 2011, including fine sediment, large woody debris, canopy, and stream units (poolriffle-run habitat), we did not continue to monitor some of the environmental variables annually beyond five years after the restoration (2002). We predicted that the restoration project would increase stream habitat diversity and enhance the fish community while perpetrating the cool-water fishery.

\section{METHODS}

\section{Executing the stream restoration}

In 1997, the University of Notre Dame constructed a golf course at the northern end of campus property that is bordered by an interstate highway and three local roads in Township 38N R3E, section 30 (Fig. 1). This area is bisected by Juday Creek, which was heavily channelized in that reach and bordered by invasive reed canary grass (Phalaris arundinacea). The reach in this section loses water to the ground from the stream (Silliman and Booth 1993, Silliman et al. 1995). Stream relocation and restoration of habitat features were incorporated into the golf course design; course construction without moving the stream would have involved substantial tree removal and the stream would have bisected several fairways, thereby increasing the potential for fine sediment runoff, nutrient and pesticide input, and warming of a cool-water stream (Lee and Lovell 1998, Moerke and Lamberti 2003, Moerke et al. 2004). The project was designed to minimize the impacts of golf course construction and management on stream biota while increasing habitat diversity and creating a selfmaintaining stream channel (Table 1). In fall 1997, two meanders were constructed $(800 \mathrm{~m}$ excavated) through deciduous forest bordering the golf course to add habitat features in a $1.2-\mathrm{km}$ channelized reach (Lee and Lovell 1998). Because this section of Juday Creek receives fine sediment runoff from upstream agriculture and urban development, an instream sediment trap (18 $\mathrm{m}$ length $\times 5 \mathrm{~m}$ width $\times 2 \mathrm{~m}$ depth) was excavated upstream of the restored reaches and downstream of an unrestored reach to minimize the impact of fine sediment on the restored reaches.

\section{Monitoring plan}

Habitat surveys, including evaluation of pools, riffles, and runs (Bisson and Montgomery 1996), were conducted one month before restoration (1997), yearly after restoration for five years (1997-2002), and again in 2011. Surveys were conducted at base flow by teams of 2-4 researchers. Substrate cores to estimate fine sediments were collected over a 3-year period (1999-2001), and again one decade later in 2011. Three cores $(10 \mathrm{~cm}$ deep, $5 \mathrm{~cm}$ diameter) were taken per reach. Substrate cores were wet- and dry-sieved into 12 size fractions, dried at $60^{\circ} \mathrm{C}$, weighed, ashed at $550^{\circ} \mathrm{C}$, and weighed to calculate dry mass and ash-free dry mass. The percent of fine sediments was calculated as (mass of sediment $<2 \mathrm{~mm}$ in diameter) divided by (total mass of the sample) multiplied by 100 . Large woody debris pieces (logs and rootwads $>1 \mathrm{~m}$ in length and $10 \mathrm{~cm}$ in diameter) were measured over the entire study reach. The volume of large woody debris was quantified using calculations for a cylinder $(\operatorname{logs})$ and cone (rootwads) (Moerke et al. 2004).

Temperatures were recorded hourly on a continuous basis in 2000-2002 during the month of July and from August 2008 through September 2013. Temperatures from the summer season 
Fig. 1. Juday Creek is a groundwater-fed, 3rd-order tributary within the St. Joseph River watershed (highlighted in light blue), which flows into Lake Michigan; the 19-km stream drains an area of $98 \mathrm{~km}^{2}$ in northwestern Indiana $\left(41^{\circ} 42^{\prime} \mathrm{N}, 86^{\circ} 13^{\prime} \mathrm{W}\right.$; elevation $\left.=206 \mathrm{~m}\right)$. The unrestored reach, U1, was located downstream of restored reaches, R1 and R2, while the unrestored reach, U2, was located upstream of the restored reaches, all within a 1.2-km stream reach in Township $38 \mathrm{~N} \mathrm{R} 3 \mathrm{E}$, section 30 bordered by Ironwood Road on the east and Interstate $80 / 90$ on the north. The stream was relocated from a channelized reach $(\mathrm{U})$ to minimize the impact of golf course fairways on stream biota.
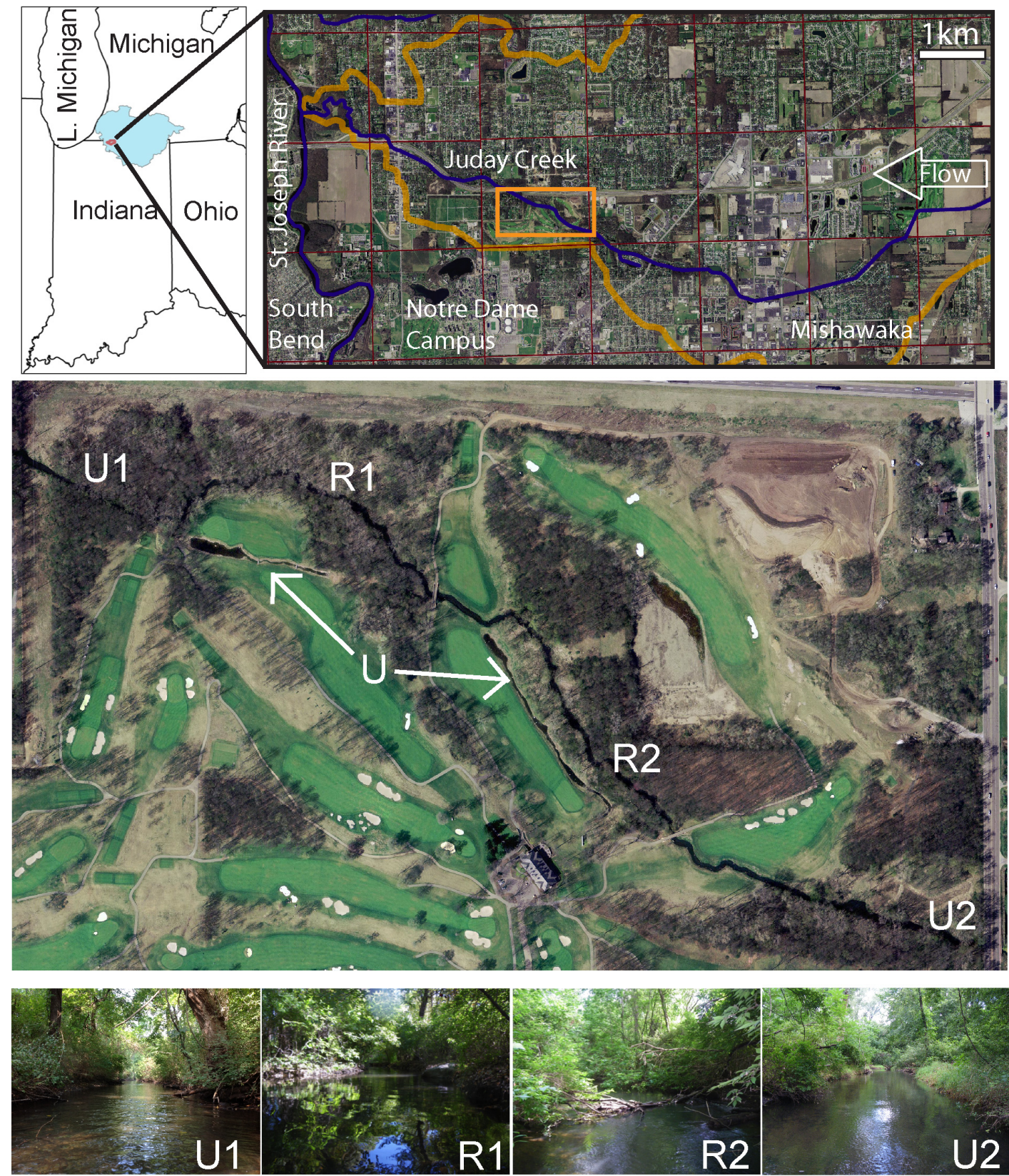

(June 1-August 31) were used to estimate proportions of time within $2^{\circ} \mathrm{C}$ of species' thermal preferences (final temperature preferrendum, optimal growth temperature) and measurements beyond species' thermal tolerance limits (upper incipient lethal temperature, critical maximum temperature) using ThermoStat 3.1 software with thermal preferences and tolerance limits defined in the software based on published information (Jones and Schmidt 2012). Discharge was obtained from United States Geological Survey gage 04101370 for October 1, 1992 through October 1, 2013. Temperature and discharge were not reported in previously published monitoring data. 
Fish surveys were conducted in two restored $(\mathrm{R} 1, \mathrm{R} 2)$ and two unrestored (U1, U2) reaches (Fig. 1) of Juday Creek two months before restoration (1997, including U-an abandoned unrestored reach) and after restoration, biannually (1998-2001) and annually (2002-2013). A 60-m section of each reach was blocked at both ends with 5-mm mesh nets and sampled with a Smith-Root backpack electrofisher, using the multiple-pass method for estimating populations from depletion (Moran 1951, Zippin 1956, 1958, Everhart et al. 1975). Fish from each pass were identified to species, measured for length and mass, and then returned to the reach.

For each reach, we calculated biomass and estimated fish population densities and 95\% confidence intervals using maximum likelihood methods from fish collected on each pass (Van Snick Gray and Stauffer 1999, Warren and Kraft 2003, Baldigo et al. 2008). MicroFish 3.0 software by Van Deventer and Platts (1989) simplifies this iterative approach by implementing the Moran-Zippin method for proportional reduction (Moran 1951, Zippin 1956, 1958). Confidence intervals from the multiplepass depletion estimates were used to compare restored and unrestored reaches, as well as absolute changes in fish populations. The lower limit of the confidence interval was adjusted to reflect actual fish captured from all passes. To explain the interpretation of a confidence interval, if we repeated samples of multiple-pass depletion and a confidence interval was computed for each sample using maximum likelihood methods, then $95 \%$ of the confidence intervals would contain the population mean. If the confidence intervals did not overlap, the differences between species population densities were considered to be significant $(p<0.05)$ (Warren and Kraft 2003). Recreational fishing, which is of concern for evaluating the effectiveness of restoration when monitoring a fish community (Thompson 2006), is restricted in the study reaches by fences surrounding the Warren Golf Course on University of Notre Dame property. We used nonmetric multidimensional scaling (NMDS) to evaluate changes in the fish community for all reaches; NMDS allowed us to evaluate how the composition of the community, as determined by counts of individual species, differed in each reach over time. The metaMDS function in the Vegan package for the statistical software $\mathrm{R}$ (Oksanen et al. 2011) was used to create an NMDS ordination to visualize spatial and temporal trends in fish communities (Ryon 2011). Fish biomass was used to calculate divergence from unrestored conditions: (restored reach biomass minus U2 biomass) divided by (abandoned, unrestored reach U 1997 minus U2 1997) multiplied by 100 .

\section{RESULTS}

\section{Habitat change}

Benthic fine sediment increased in the restored reaches from 1999 to 2011, by a factor of 12 for R1 and a factor of 3 for R2 (Table 2). In contrast to the restored reaches, the fine sediment in the unrestored reaches did not change from 1999 to 2011 (Table 2). Pool size and number decreased over time as pools filled with fine sediment, and the pool-riffle ratio increased, approaching the prerestoration ratio (Fig. 2). In addition, canopy cover increased substantially from 1998 to 2011 for both restored reaches (by about $300 \%$ in both reaches), which exceeded the original goal of a $67 \%$ increase over 10 years postrestoration to shade and cool the stream (Tables 1,3). The volume of large wood volume was initially high in the new reaches $\mathrm{R} 1$ and $\mathrm{R} 2$ (due to wood placement during restoration) but decreased by $53 \%$ in $\mathrm{R} 1$ and $32 \%$ in R2 from 1997 to 2011 due to decomposition, breakage, and fine sediment covering the wood, coupled with lack of recruitment of new wood (Table 3). In contrast, the volume of large wood increased by $6000 \%$ in U1 and $2500 \%$ in U2 due to recruitment from fallen trees. In 2011, wood volume in the unrestored reaches surpassed that in the restored reaches.

Table 2. Mean percent fine sediment (standard error) in riffle habitat of four reaches of Juday Creek.

\begin{tabular}{ccccc}
\hline \hline & 1999 & 2000 & 2001 & 2011 \\
\hline U1 & $65.97(6.39)$ & $67.35(4.02)$ & $55.65(8.65)$ & $56.02(11.99)$ \\
R1 & $2.59(0.55)$ & $2.12(0.79)$ & $3.33(1.19)$ & $24.77(5.02)$ \\
R2 & $5.39(1.25)$ & $10.66(4.39)$ & $13.08(0.08)$ & $32.41(5.40)$ \\
U2 & $70.36(5.47)$ & $80.03(3.31)$ & $80.14(1.76)$ & $62.41(5.01)$ \\
\hline
\end{tabular}

Fig. 2. Habitat surveys in 2011 showed a lower pool:riffle ratio since restoration and an increase in the amount of riffle habitat. Pool-riffle length ratios were calculated for the entire 1-km study reach after restoration. Figure modified and updated from Moerke (2004).

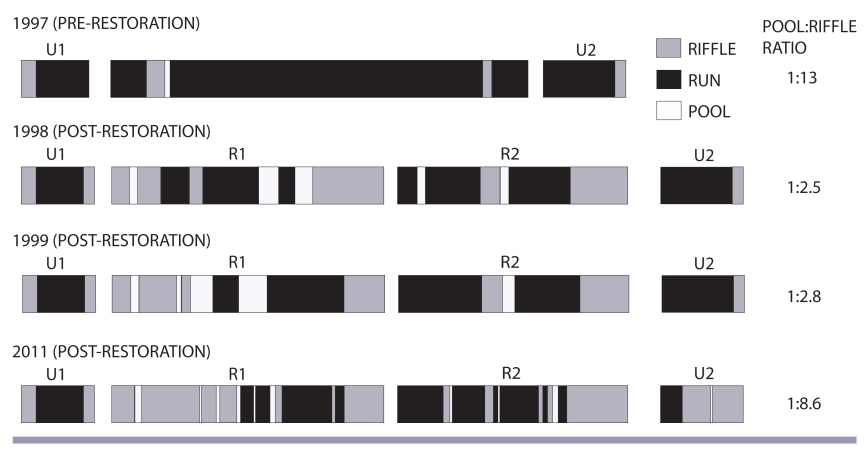

Table 3. Habitat characteristics of restored (R1, R2) and unrestored (U1, U2) reaches of Juday Creek (updated from Moerke et al. 2004).

\begin{tabular}{|c|c|c|c|c|c|c|c|}
\hline & \multicolumn{4}{|c|}{$\begin{array}{l}\text { Large woody debris (volume } \mathrm{m}^{3} / \\
\qquad \mathrm{m}^{2} \text { ) }\end{array}$} & \multicolumn{3}{|c|}{ Canopy $(\%)$} \\
\hline & U1 & R1 & R2 & U2 & R1 & R2 & U2 \\
\hline $\begin{array}{l}1997 \\
\text { pre }\end{array}$ & 0.005 & - & - & 0.039 & - & - & - \\
\hline $\begin{array}{l}1997 \\
\text { post }\end{array}$ & 0.261 & 0.620 & 0.773 & 0.066 & - & - & 57 \\
\hline 1998 & 0.131 & 0.549 & 0.711 & 0.123 & 23 & 27 & 57 \\
\hline 1999 & 0.216 & 0.651 & 0.672 & 0.140 & 34 & 25 & 63 \\
\hline 2000 & 0.300 & 0.479 & 0.586 & 0.331 & 58 & 54 & 77 \\
\hline 2001 & 0.232 & 0.439 & 0.499 & 0.273 & 62 & 63 & 86 \\
\hline 2002 & 0.176 & 0.397 & 0.496 & 0.331 & 67 & 53 & 75 \\
\hline 2011 & 0.307 & 0.290 & 0.527 & 0.975 & 86 & 76 & 80 \\
\hline
\end{tabular}

July temperatures did not show a discernible pattern over time (Table 4). Temperatures (2009-2013) exceeded the upper incipient lethal temperature for mottled sculpin (Cottus bairdii) for 3.0\% of the summer season, and for brown trout and rainbow trout for $1.4 \%$ of the summer season (Table 5 ). 
Table 4. July temperatures (degrees Celsius) of Juday Creek at the Warren Golf Course. Temperatures were recorded hourly on a continuous basis from August 2008 through September 2013, and in 2000-2002 during the month of July.

\begin{tabular}{lccccccccc}
\hline \hline & 2000 & 2001 & 2002 & - & 2009 & 2010 & 2011 & 2012 & 2013 \\
\hline Mean & 18.9 & 21.5 & 21.2 & - & 18.6 & 21.3 & 20.7 & 18.4 & 20.5 \\
Max & 22.7 & 27.6 & 25.8 & - & 22.1 & 27.0 & 25.5 & 25.7 & 27.1 \\
Min & 15.7 & 15.9 & 16.8 & - & 15.0 & 15.8 & 16.3 & 12.5 & 15.7 \\
\hline
\end{tabular}

\section{Fish response}

The fish community shifted from trout to bass over time (Fig. 3, 4). During the intermediate years of this shift when we observed few trout or bass, populations of minnows (blacknose dace [Rhinichthys atratulus], creek chub [Semotilus atromaculatus]) increased in proportional abundance in the fish community (Fig. 3). The U1 fish community was least similar to the other reaches over time, contained fewer total fish, and was composed primarily of creek chub and blacknose dace (Fig. 4). No rock bass (Ambloplites rupestris), smallmouth bass (Micropterus dolomieu), or largemouth bass (Micropterus salmoides) were collected in 1997 prior to restoration, and were rarely found before 2003. Since 2003 , the year that brown trout and rainbow trout started to decline, rock bass and smallmouth bass gradually increased in all reaches surveyed (Fig. 5). Additional species occasionally collected from the restored and unrestored reaches included bluegill (Lepomis macrochirus), central mudminnow (Umbra limi), pumpkinseed (Lepomis gibbosus), rainbow darter (Etheostoma caeruleum) (2012, 2013), yellow perch (Perca flavescens), and warmouth (Lepomis gulosus).

Fig. 3. Fish family relative abundance for prerestoration (1997) and 5-year increments postrestoration to show change through time. R2 and R1 were sampled as one unit within the previous (abandoned) channel prior to restoration.

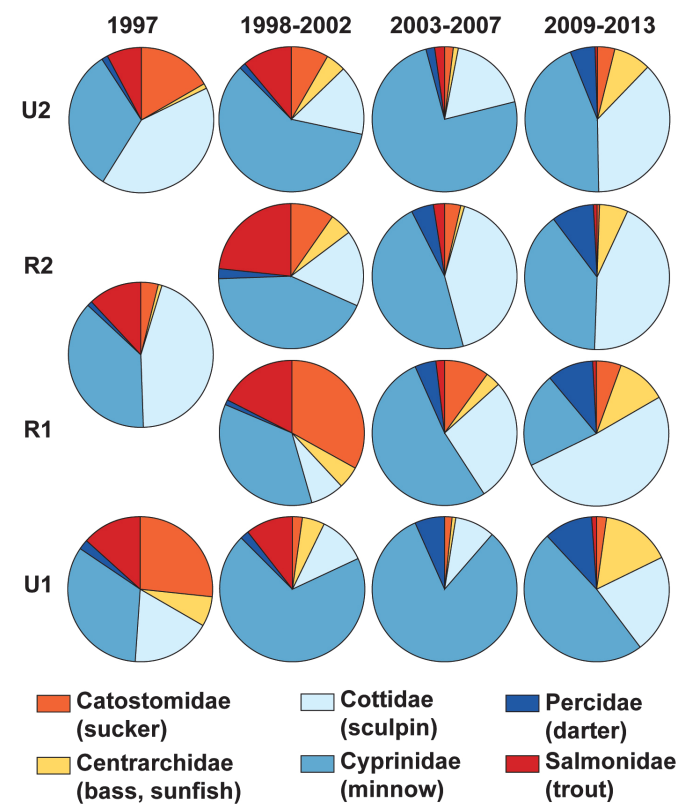

Fig. 4. Nonmetric multidimensional scaling (NMDS) plot of fish communities at four Juday Creek sites (unrestored: U1 is shown as circles, U2 is shown as squares; restored: R1 is shown as downward pointing triangles, $\mathrm{R} 2$ is shown as upward pointing triangles) from 1997 through 2012. Larger shapes represent higher biomass than smaller shapes. Shading shows communities over time from dark (1997) to light (2012). Fish communities that are similar in species compositions appear closer in ordination space than those fish communities that differ in species compositions. For example, the fish communities of R1 and R2 were similar to one another in 1998 and 1999, when brown trout were a large proportion of the fish community by abundance. In 2012, the fish communities of R1 and R2 were also similar but with higher proportional abundances of smallmouth bass and rock bass. This change is illustrated by a shift of R1 and R2 symbols from the left side of the plot (1998/99) to the right side (2012). Arrows emphasize community shift over time.

\section{Sites (Fish communities) In(biomass $\left[\mathrm{g} / \mathrm{m}^{2}\right]$ )

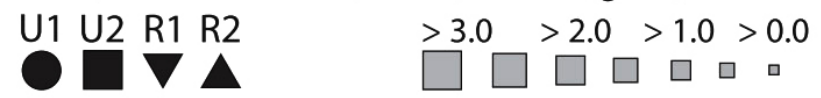

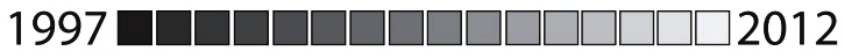

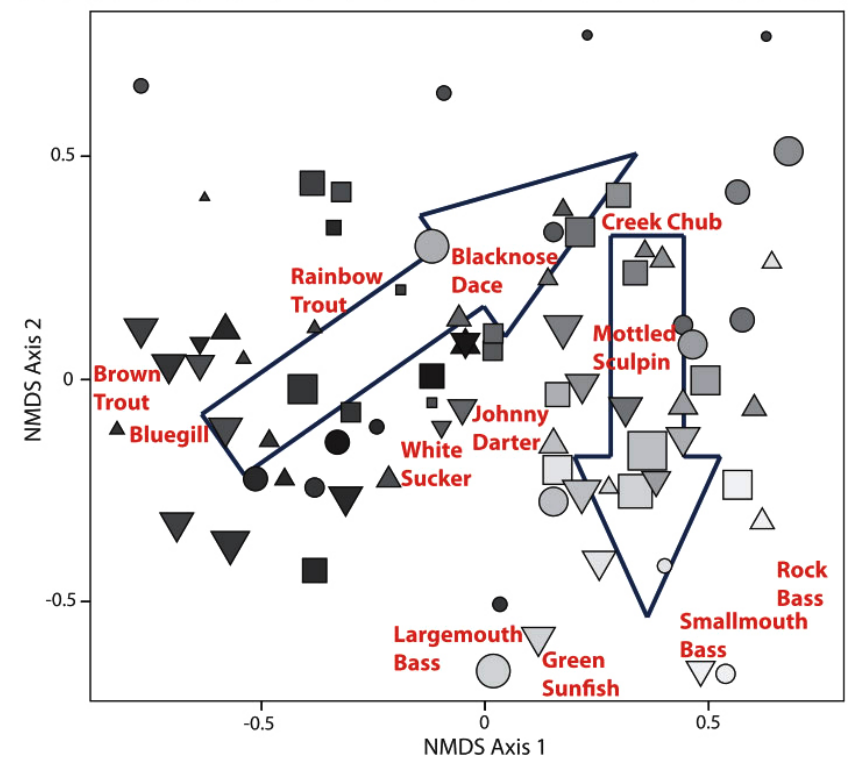

The mottled sculpin population took six years to recover to prerestoration abundances in R2 but did not significantly differ from the prerestoration estimates over the last three years. However, the population in $\mathrm{R} 2$ had a higher abundance than the upstream, unrestored site (U2) in eight out of the last 11 years and averaged four times more fish since restoration compared to U2 (Fig. 6). Since recovery to prerestoration levels, the result of the restoration effort for mottled sculpin varied annually when comparing R1 with the upstream, unrestored reach (U2). In the downstream, unrestored reach (U1), species that increased in abundance when comparing 1997 with 2013 included blacknose dace, creek chub, green sunfish (Lepomis cyanellus), Johnny darter (Etheostoma nigrum), and mottled sculpin (Fig. 6). Surveys in every year but 2008 indicated that numbers of blacknose dace 
Table 5. Percent of Juday Creek summer season (June 1-August 31, 2009-2013) temperature measurements within $2^{\circ} \mathrm{C}$ of species' thermal preferences (final temperature preferrendum [FTP]; optimal growth temperature [OGT]) and beyond species' thermal tolerance limits (upper incipient lethal temperature [UILT]; critical maximum temperature [CTmax]), as calculated using ThermoStat 3.1 software (Jones and Schmidt 2012).

\begin{tabular}{|c|c|c|c|c|c|}
\hline Species & Common name & FTP & OGT & UILT & CTmax \\
\hline Ambloplites rupestris & Rock bass & 9.0 & 0.2 & 0.0 & 0.0 \\
\hline Catostomus commersonii & White sucker & 22.7 & 5.9 & 0.0 & 0.0 \\
\hline Cottus bairdii & Mottled sculpin & 26.3 & - & 3.0 & 0.0 \\
\hline Etheostoma caeruleum & Rainbow darter & 60.1 & - & - & 0.0 \\
\hline Lepomis cyanellus & Green sunfish & 6.6 & 0.4 & 0.0 & 0.0 \\
\hline Micropterus dolomieu & Smallmouth bass & 8.4 & 4.0 & 0.0 & 0.0 \\
\hline Micropterus salmoides & Largemouth bass & 0.2 & 2.2 & 0.0 & 0.0 \\
\hline Oncorhynchus mykiss & Rainbow trout & 16.9 & 19.1 & 1.4 & 15.8 \\
\hline Rhinichthys atratulus & Blacknose dace & 60.6 & - & 0.0 & 0.0 \\
\hline Salmo trutta & Brown trout & 19.1 & 1.0 & 1.4 & 0.0 \\
\hline Semotilus atromaculatus & Creek chub & 9.0 & - & 0.0 & 0.0 \\
\hline
\end{tabular}

Fig. 5. Population estimates of (A) introduced Salmonidae (brown trout, rainbow trout) and (B) native Centrarchidae (rock bass, smallmouth bass, largemouth bass) from multiplepass data for each 60-m reach (prerestoration in 1997; postrestoration 1998 through 2013). Error bars indicate 95\% confidence intervals.
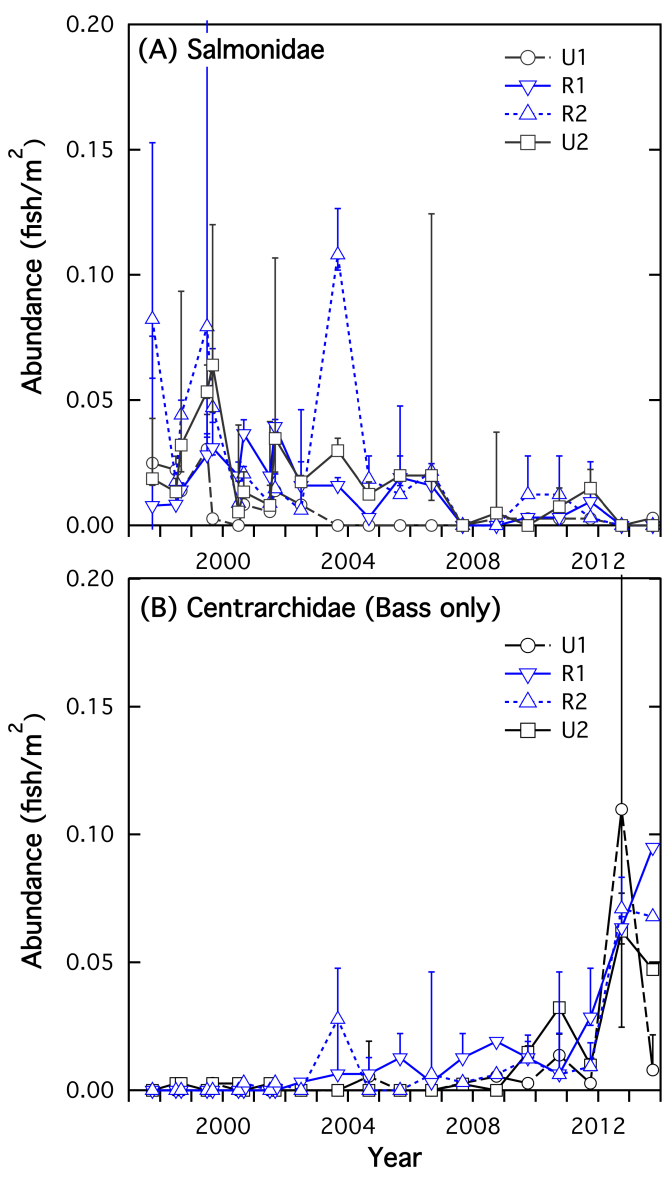

were significantly lower in R1 after restoration than in $\mathrm{U} 2$, and compared to prerestoration levels. In R2, numbers of dace were significantly lower than in U2 and compared to prerestoration levels in eight years (1998-2002, 2004, 2011-2012). Green sunfish (since 2006) and Johnny darter (since 2003) increased in all four reaches. White sucker (Catostomus commersonii) estimates in $\mathrm{R} 1$ were higher in most years compared to the prerestoration survey and the unrestored reach (U2). In contrast, numbers of white sucker in R2 were not significantly higher than in the unrestored reach (U2) after 2002, and decreased in the downstream, unrestored reach (U1) after 1997. The calculation of percent recovery takes into account that fish biomass was higher in the prerestoration reach $U\left(9.2 \mathrm{~g} / \mathrm{m}^{2}\right)$, which was abandoned, than in $\mathrm{U} 2\left(6.9 \mathrm{~g} / \mathrm{m}^{2}\right)$ in 1997 . Fish biomass increased by an average of $309 \%$ postrestoration for R1 and decreased by an average of $130 \%$ for R2 (Fig. 7).

\section{DISCUSSION}

We evaluated the response of Juday Creek habitat conditions and fish populations to a channel relocation and reach-level restoration. Seventeen years of monitoring data provided unique insights about changes in habitat and the fish community that five years of data did not provide. Our results document that the restoration project achieved its original purpose of minimizing the impacts of the golf course on stream biota while increasing stream habitat diversity and creating a self-maintaining stream channel. Our study demonstrates that long-term monitoring of stream restoration projects ( $>5$ years) is critical for determining ecological responses to habitat manipulations (e.g., Orzetti et al. 2010, Ryon 2011). For example, Ryon (2011) evaluated fish community response to pollution abatement over 20 years in Brushy Fork in Oak Ridge, Tennessee, and concluded that a shorter monitoring effort would not have allowed observation of a trend toward recovery compared to reference conditions. In addition, willingness to adapt management to changing circumstances is important for evaluating outcomes (O'Donnell and Galat 2008). For example, protecting or enhancing habitat for non-native brown trout and rainbow trout was a specific goal of the stream reach relocation, and thus a focus of restoration efforts (Moerke and Lamberti 2003). While the decline in trout abundance and biomass might lead to conclusions that the project did not achieve its intended goals, the increase in total abundance and biomass of other fish species (e.g., native bass species) suggests 
Fig. 6. Population estimates of six species that were recorded for all 17 years of monitoring using multiple-pass data for each 60-m reach of Juday Creek: (A) blacknose dace, (B) green sunfish, (C) Johnny darter, (D) creek chub, (E) white sucker, and (F) mottled sculpin. Error bars indicate $95 \%$ confidence intervals.
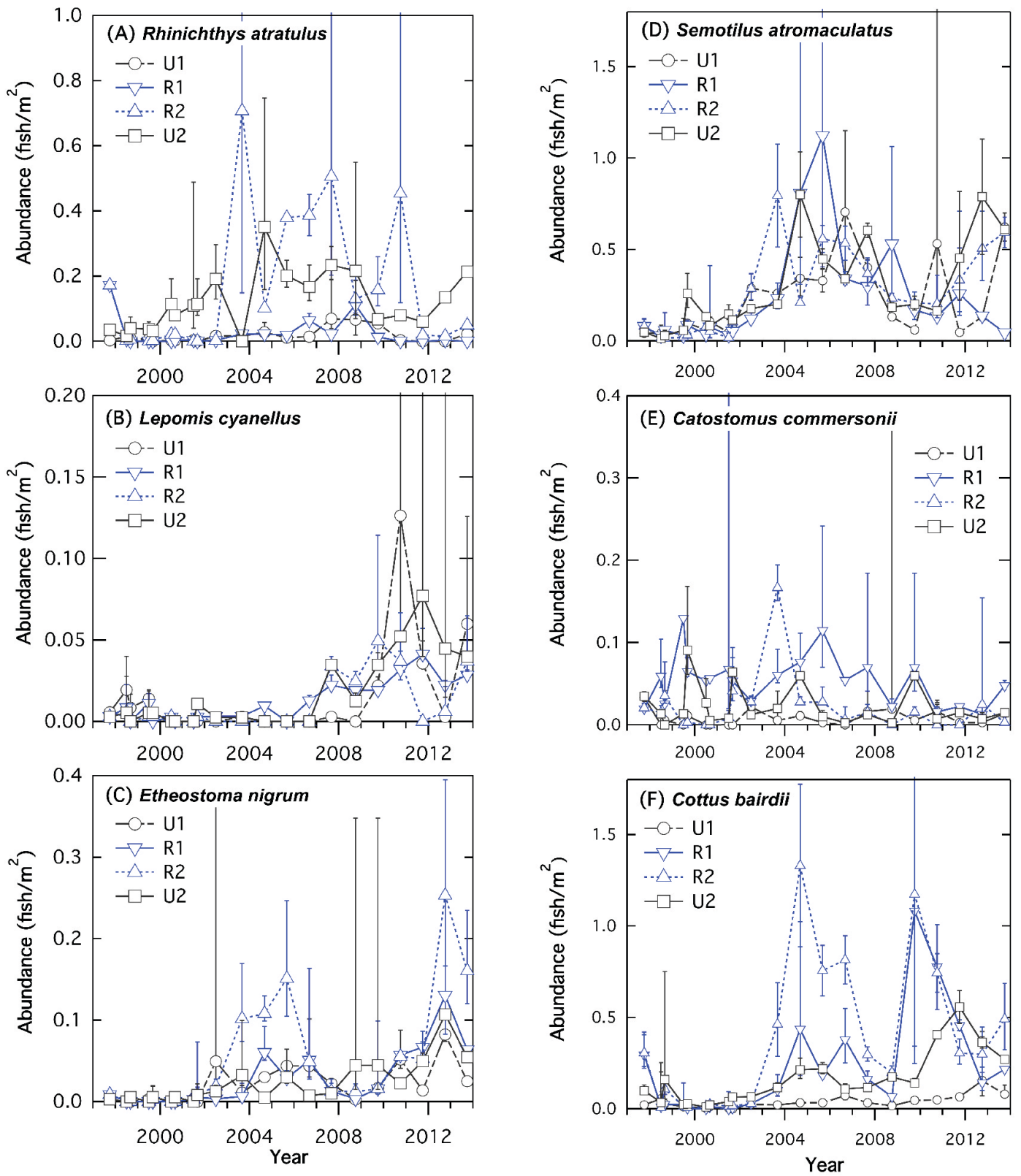

a transition of this stream reach to a native fish assemblage. We discuss the insights from that transition, including possible reasons for the change, to pose, evaluate, and recalibrate management hypotheses as a function of potential ecological outcomes of management interventions into an adaptive management framework when setting goals to restore streams.

The shift in the fish community could be due to a combination of factors, including (1) increased temperature, (2) periods of extremely low discharge, (3) shifts in habitat that favor bass and disfavor their competitors or predators, and (4) fish stocking.
First, we do not have evidence to suggest that water temperature alone is responsible for the change, as summer temperatures (June 1-August 31) exceeded upper incipient lethal temperature for brown trout and rainbow trout only $1.4 \%$ of the time measured from June 2009 through August 2013. Trout would likely be able to seek refuge in pools and areas of upwelling groundwater (Baird and Krueger 2003), especially in gaining reaches upstream of the study site (Silliman and Booth 2003). Furthermore, recent August temperatures have not been warmer than the average temperatures that were recorded for this section of Juday Creek in the early 1990s (Silliman and Booth 1993, Silliman et al. 1995). 
Fig. 7. Total fish biomass (A) was used to calculate percent recovery of fish biomass relative to prerestoration; (B): (restored reach biomass minus U2 biomass) divided by (U 1997 minus U2 1997) multiplied by 100. Dashed line represents $100 \%$ recovery; at this point, the restored reach would have equal biomass difference compared with the unrestored reach (U2) relative to the prerestoration biomass difference $\left(2.3 \mathrm{~g} / \mathrm{m}^{2}\right)$ between $\mathrm{U}$ and $\mathrm{U} 2$.
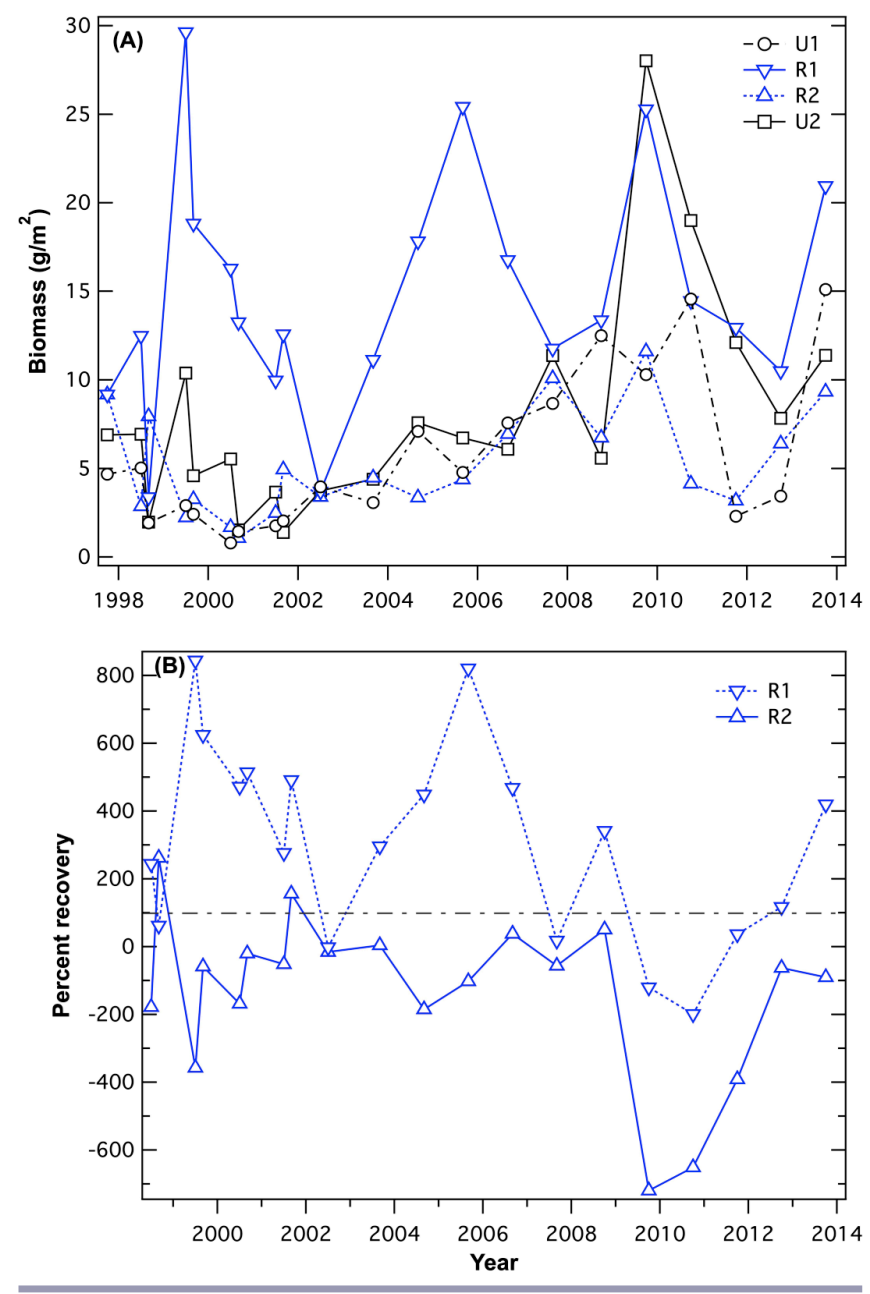

Second, low discharge could be a factor that contributed to the fish community change. Initially, the restoration appeared to have a positive effect on trout spawning and recruitment (Moerke and Lamberti 2003), but trout populations started to decline in 2003, coinciding with low discharge in the winter of 2002-2003. Furthermore, discharge dropped below a mean of $0.03 \mathrm{~m}^{3} / \mathrm{s}$ (and reached a minimum of $0.017 \mathrm{~m}^{3} / \mathrm{s}$ ) for the month of October 2005 , whereas the stream flow typically averages $0.4 \mathrm{~m}^{3} / \mathrm{s}$. This low flow would have created considerable abiotic stress on the fish community, especially cool-water species such as salmonids.

Third, we cannot rule out that changing habitat conditions in the watershed and our study sites might have reduced spawning habitat for trout, as small increases in riffle embeddedness, as we have observed in the restored reaches, can reduce recruitment of young trout (Jones et al. 2006). The increase in fine sediment in the restored reaches may have contributed to the decline of brown trout and rainbow trout. This fine sediment can likely be attributed to (1) the stream's natural sediment load that will deposit fine sediments over time (Fowler and Wilson 1995), (2) land development and watershed management that contribute fine sediment inputs to the watershed (Kohlhepp and Hellenthal 1992, Lamberti and Berg 1995), and (3) the fact that the sediment trap constructed upstream of the restored reaches was not excavated between 2003 and 2013. That fine sediment did not change in the unrestored reaches from 1999 to 2011 likely reflects a stable state of sediment accumulation and routing.

In addition to these habitat changes that likely contributed to the decline of trout, the wood that was added in the restoration reach and that was naturally recruited in the unrestored reaches may have enhanced spawning habitat for rock bass and smallmouth bass, which were collected in pools with large wood cover. An expected added biological benefit of the restoration project rerouting the stream through a wooded area was the contribution of fallen branches and downed trees to the stream, as large woody debris can increase ecological structure and function (Bilby and Likens 1980, Ehrman and Lamberti 1992, Gregory et al. 2003, Cordova et al. 2007). Wood debris jams that can be sustained for positive feedback to macroinvertebrates and fish are a particularly important component of stream restoration projects (Manners and Doyle 2008). While we found reduced volume of large woody debris in the restored reaches, it increased in the unrestored reaches over time.

Finally, stocking played a role in establishing populations of brown and rainbow trout in Juday Creek as early as 1903. However, the Indiana Department of Natural Resources has not stocked Juday Creek with brown trout since records were kept in 1962 , though the stream was used as a discarded stocking location for small rainbow trout in 2005 and 2006, which may explain the observations of rainbow trout in subsequent years. One fishing club stocked several hundred brown trout in the mid-1990s without a stocking permit (Neil Ledet, Indiana Department of Natural Resources, personal communication). Landowners have stocked Centrarchidae in residential ponds that are artificially connected to Juday Creek upstream of the study site, and these fish can likely colonize the stream during overbank flooding.

The restoration project appears to have benefited populations of nongame fishes. However, more than five years after the restoration, we observed a delayed population increase for mottled sculpin and Johnny darter, coincident with a decline in brown trout. Possible explanations for this favorable response to the restoration include the following: (1) these species take longer to respond to habitat change, (2) their abundance is inversely proportional to the abundance of brown trout, likely due to predation, or (3) a combination of both.

Given that mottled sculpin display nest-guarding behavior near coarse substrate (Matheson and Brooks 1983), nest-guarding males likely exploited the cobble and gravel substrate that was added to the restoration (Moerke et al. 2004). In addition to the benefits conferred to mottled sculpin by added gravel, the shallow, riffle habitat of R2 likely provides nursery and refuge for young sculpin, which may have a positive effect if sculpin disperse as adults. For example, mottled sculpin populations were higher over 
the last four years (2010-2013) for U1 and U2 by a factor of 4 compared to prerestoration in 1997. Although individuals can disperse over longer distances, only a small percentage of sculpin move $>100 \mathrm{~m}$ in one year, and most individuals are relatively sedentary (Breen et al. 2009). The relatively short dispersal distance, coupled with our observation that mottled sculpin did not recover to prerestoration levels for $>5$ years postrestoration, demonstrates the importance of monitoring restoration projects over sufficiently long periods to assess responses of slow-colonizing species. In addition, mottled sculpin may have been suppressed by piscivorous brown trout soon after restoration, which can also negatively impact the growth of a similar sculpin species (Zimmerman and Vondracek 2007). Brown trout may have also slowed the colonization of Johnny darter, which are typically found over sand substrate without cover (Pratt and Lauer 2013).

In contrast to these species, creek chub are able to disperse long distances over short periods (Belica and Rahel 2008) and thrive in small, clear, cool-water streams with alternating pool and riffle habitat. We suspect that the delayed formation of debris jams that provide food (macroinvertebrates) and cover may explain the delayed increase in numbers of creek chub in the created channel relative to prerestoration population estimates in the unrestored reach. We also found blacknose dace in pools below debris jams. However, blacknose dace, along with green sunfish and white suckers, are relatively tolerant of polluted and silted habitat. While the presence of these pollution-tolerant species contributes to the management goal of maintaining a diverse fish community, their abundance is less useful as a metric for evaluating water quality compared to species like rock bass.

While we benefit from long-term data that show a shift in the fish community, our interpretations are also limited by one sampling period before the restoration, a nonreplicated study design, and the fact that the reaches are not independent. Regardless, our results suggest there are ongoing changes in the watershed that exert greater influence on biota than the reach-scale restoration, similar to observations from other studies in urban watersheds that show land use and watershed conditions exert greater influence on organisms than habitat heterogeneity (Rios-Touma et al. 2014, Smucker and Detenbeck 2014). A long-term perspective on the fish community within the watershed, coupled with life history requirements of individual species, is necessary to inform and plan future management efforts (Kemp 2014). For example, populations of central mudminnow and American pickerel (Esox americanus) were historically more abundant in this section of Juday Creek (Marenchin and Sever 1981). Just a few hundred meters upstream of U2, the ecology of the central mudminnow was studied in the 1950 s, when the population was very abundant due to the availability of vegetated backwater habitat (Peckham and Dineen 1957). The low abundance of central mudminnow is not surprising, given the loss of this off-channel habitat for spawning and foraging, likely due to management actions to stabilize and harden stream banks. Though American pickerel may still be present in ponds adjacent to the stream on private land, the species has not been collected in more than 100 electrofishing surveys of the stream since the species was found near the mouth in 1992, which suggests a lack of adequate vegetated habitat for the species throughout the watershed. If the public decides to restore habitat for these species and continue to provide habitat for species like rock bass and smallmouth bass, then efforts to learn from restoration project and management outcomes, to recalibrate management hypotheses as a function of ecological outcomes of monitoring, and to educate the public will be important, especially if enhancing the biodiversity of fishes in the watershed is a targeted goal.

A challenging but important management issue is informing the public about the ecological requirements of the native fish assemblage, and the role of introduced fish in structuring that community. Some local anglers desire opportunities to fish for brown trout and rainbow trout; however, maintaining these introduced trout in a stream like Juday Creek may be unsustainable if cold-water inputs in the headwaters diminish due to changing land use and water withdrawal. Furthermore, stocking and reachscale restoration provide a temporary solution to the demands of anglers, but suitable habitat conditions are required for recruitment of fish populations. A flashier hydrograph with more extreme peak and low flows and declining discharge is likely to result from continued urban development (Walsh et al. 2005). Without restoration of wetlands in the watershed to store water on the landscape, we expect fall flows to remain too low to maintain largebodied trout and eggs within redds during months of low flow. Unlike trout, which spawn in gravel often near areas of upwelling, bass guard their nests and are able to fan silt away from their eggs; this reproductive strategy is more successful during periods of low discharge because rock bass tend to build their nests in shallow water on gravel and sand underneath cover such as logs, and are commonly found in hard-bottomed streams in Indiana near undercut banks, large rocks, and woody debris (Gerking 1945).

Managers and anglers may need to adjust their expectations as a result of changing climate and further change of agricultural and wooded land into commercial and residential property. In addition, an important component of education regarding fisheries is informing the public that one consequence of non-native trout may be reductions in the native fish assemblage. If the native fish assemblage is important to the public, then other native sport fish that appear to be increasing in Juday Creek (e.g., bass) could be promoted to the local angling public as a sustainable sport fishery. The public may then wish to weigh the benefits of managing nonnative brown trout against the benefits of maintaining a native fishery (Hoxmeier and Dieterman 2013). From a watershed perspective, the presence of rock bass could be viewed as an encouraging sign because individuals are intolerant of silt and pollution (Poff and Allan 1995, Simon and Dufour 1997, Lau et al. 2006).

\section{CONCLUSIONS}

The results of this research demonstrate the importance of monitoring long-term ecological responses to stream restorations. The positive response of the native fish community in the restored reaches downstream of active watershed development highlights the success of efforts to reduce watershed-level inputs of fine sediments and pollutants to the stream. The restoration did not enhance the introduced brown trout fishery-an initial (perhaps misguided) goal of the restoration project. Rather, a possible related benefit of trout declines was an increase in native predators. If a stream management goal is to promote diversity of native fish species, then the colonization of the restored stream reaches by native sportfish (e.g., smallmouth bass) and fish that are sensitive to pollution (e.g., rock bass) can be viewed as a positive outcome. Another option for setting goals in the future is to adopt an adaptive 
management approach that allows for learning from each watershed action or restoration project to adjust management decisions as additional knowledge is gained. Combined with longterm monitoring, actions can be implemented based on quantitative evidence to improve environmental quality to benefit aquatic biota and public resource users.

Responses to this article can be read online at: http://www.ecologyandsociety.org/issues/responses. $\mathrm{php} / 8584$

\section{Acknowledgments:}

P.D.S. was supported by a fellowship from the NSF IGERT grant award \#0504495 to the GLOBES graduate training program at the University of Notre Dame (UND), with additional funding provided by the UND Environmental Change Initiative's Center for Aquatic Conservation Fellowship, a UND CEST Bayer Predoctoral Research Fellowship, and the George Melendez Wright Climate Change Fellowship from the National Park Service. J.B.K. was supported by a REU from the GLOBES NSF IGERT award. Numerous Notre Dame staff, undergraduate researchers, and graduate students contributed to the sampling effort in Juday Creek over the course of this nearly 20-year study, as did many friends of the Stream Ecology Laboratory (Appendix 1). To all, we are extremely grateful. We especially thank Ronald A. Hellenthal for his contributions to research on Juday Creek, input on this manuscript, and dedication to protecting Juday Creek through service to the Juday Creek Task Force; Ashley Moerke for her input on this manuscript and previous work on this project through her dissertation; and, Dominic Chaloner for providing temperature data. We also recognize the Pokagon Band of Potawatomi, and the displaced Potawatomi and Miami, whose ancestors were the previous caretakers of Juday Creek.

\section{LITERATURE CITED}

Baird, O. E., and C. C. Krueger. 2003. Behavioral thermoregulation of brook and rainbow trout: comparison of summer habitat use in an Adirondack river, New York. Transactions of the American Fisheries Society 132:1194-1206. http://dx.doi.org/10.1577/T02-127

Baldigo, B. P., D. R. Warren, A. G. Ernst, and C. I. Mulvihill. 2008. Response of fish populations to natural channel design restoration in streams of the Catskill Mountains, New York. North American Journal of Fisheries Management 28:954-969. http://dx.doi.org/10.1577/M06-213.1

Bash, J. S., and C. M. Ryan. 2002. Stream restoration and enhancement projects: is anyone monitoring? Environmental Management 29:877-885. http://dx.doi.org/10.1007/s00267-001-0066-3

Belica, L. A. T., and F. J. Rahel. 2008. Movements of creek chubs, Semotilus atromaculatus, among habitat patches in a plains stream. Ecology of Freshwater Fish 17:258-272. http://dx.doi. org/10.1111/j.1600-0633.2007.00277.x

Benidickson, J. 2007. The culture of flushing: a social and legal history of sewage. University of British Columbia Press, Vancouver, British Columbia, Canada.
Benke, A. C. 1990. A perspective on America's vanishing streams. Journal of the North American Benthological Society 9:77-88. http://dx.doi.org/10.2307/1467936

Bernhardt, E. S., M. A. Palmer, J. D. Allan, G. Alexander, K. Barnas, S. Brooks, J. Carr, S. Clayton, C. Dahm, J. Follstad-Shah, D. Galat, S. Gloss, P. Goodwin, D. Hart, B. Hassett, R. Jenkinson, S. Katz, G. M. Kondolf, P. S. Lake, R. Lave, J. L. Meyer, T. K. O'Donnell, L. Pagano, B. Powell, and E. Sudduth. 2005. Synthesizing U.S. river restoration efforts. Science 308:636-637. http://dx.doi.org/10.1126/science.1109769

Bilby, R. E., and G. E. Likens. 1980. Importance of organic debris dams in the structure and function of stream ecosystems. Ecology 61:1107-1113. http://dx.doi.org/10.2307/1936830

Bisson, P. A., and D. R. Montgomery. 1996. Valley segments, stream reaches, and channel units. Pages 23-52 in F. R. Hauer and G. A. Lamberti, editors. Methods in Stream Ecology. Academic Press, San Diego, California.

Breen, M. J., C. R. Ruetz, III, K. J. Thompson, and S. L. Kohler. 2009. Movements of mottled sculpins (Cottus bairdii) in a Michigan stream: how restricted are they? Canadian Journal of Fisheries and Aquatic Sciences 66:31-41. http://dx.doi. org/10.1139/F08-189

Cordova, J. M., E. J. Rosi-Marshall, A. M. Yamamuro, and G. A. Lamberti. 2007. Quantity, controls and functions of large woody debris in Midwestern USA streams. River Research and Applications 23:21-33. http://dx.doi.org/10.1002/rra.963

Ehrman, T. P., and G. A. Lamberti. 1992. Hydraulic and particulate matter retention in a $3^{\text {rd }}$-order Indiana stream. Journal of the North American Benthological Society 11:341-349. http:// dx.doi.org/10.2307/1467556

Everhart, W. H., A. W. Eipper, and W. D. Young. 1975. Principles of fishery science. Cornell University Press, Ithaca, New York, USA.

Fowler, K. K., and J. T. Wilson. 1995. Characteristics, transport and yield of sediment in Juday Creek, St. Joseph County, Indiana, 1993-94. Prepared in cooperation with the Indiana Department of Natural Resources, Division of Water and the St. Joseph County Drainage Board. U.S. Geological Survey, Indianapolis, Indiana. Report 95-4135.

Gerard, K. 2005. The effects of stream restoration and sediment removal on community dynamics and secondary production rates of benthic invertebrates in Juday Creek, Indiana. Dissertation. University of Notre Dame, Notre Dame, Indiana, USA.

Gerking, S. D. 1945. The distribution of the fishes of Indiana. Investigations of Indiana lakes and streams. Volume 3. Indiana Department of Conservation, Indianapolis and Indiana University, Department of Zoology, Bloomington, Indiana, USA.

Gregory, S. V., K. L. Boyer, and A. M. Gurnell, editors. 2003. The ecology and management of wood in world rivers. American Fisheries Society, Bethesda, Maryland, USA.

Hoxmeier, R. J. H., and D. J. Dieterman. 2013. Seasonal movement, growth and survival of brook trout in sympatry with brown trout in Midwestern US streams. Ecology of Freshwater Fish 22:530-542. http://dx.doi.org/10.1111/eff.12051 
Jansson, R., H. Backx, A. J. Boulton, M. Dixon, D. Dudgeon, F. M. R. Hughes, K. Nakamura, E. H. Stanley, and K. Tockner. 2005. Stating mechanisms and refining criteria for ecologically successful river restoration: a comment on Palmer et al. 2005. Journal of Applied Ecology 42:218-222. http://dx.doi. org/10.1111/j.1365-2664.2005.01022.X

Jones, K. L., G. C. Poole, J. L. Meyer, W. Bumback, and E. A. Kramer. 2006. Quantifying expected ecological response to natural resource legislation: a case study of riparian buffers, aquatic habitat, and trout populations. Ecology and Society 11(2): 15. [online] URL: http://www.ecologyandsociety.org/vol11/iss $2 /$ $\underline{\operatorname{art} 15 /}$

Jones, N. E., and B. Schmidt. 2012. ThermoStat Version 3.0: Tools for analyzing thermal regimes. Ontario Ministry of Natural Resources, Aquatic Research and Development Section, Ontario, Canada.

Kauffman, J. B., R. L. Beschta, N. Otting, and D. Lytjen. 1997. An ecological perspective of riparian and stream restoration in the western United States. Fisheries 22:12-24. http://dx.doi. org/10.1577/1548-8446(1997)022<0012:AEPORA>2.0.CO:2

Kemp, S. 2014. The potential and limitations of linking biological monitoring data and restoration needs of urbanized waterways: a case study. Environmental Monitoring and Assessment 186:38593873. http://dx.doi.org/10.1007/s10661-014-3663-3

Klein, L. R., S. R. Clayton, J. R. Alldredge, and P. Goodwin. 2007. Long-term monitoring and evaluation of the Lower Red River Meadow Restoration Project, Idaho, U.S.A. Restoration Ecology 15:223-239. http://dx.doi.org/10.1111/j.1526-100X.2007.00206. $\underline{\mathrm{x}}$

Kohlhepp, G. W., and R. A. Hellenthal. 1992. The effects of sediment deposition on insect populations and production in a northern Indiana stream. Pages 73-84 in T. P. Simon and W. S. David, editors. Proceedings of the 1991 Midwest Pollution Control Biologists Meeting: Environmental Indicators: Measurement and Assessment Endpoints. EPA 905/R-92/003. U.S. Environmental Protection Agency Region V, Environmental Sciences Division, Chicago, Illinois, USA.

Lamberti, G. A., and M. B. Berg. 1995. Invertebrates and other benthic features as indicators of environmental change in Juday Creek, Indiana. Natural Areas Journal 15:249-258.

Latimore, J. A. 2000. Impacts of golf course construction and stream diversion on benthic invertebrates and sediment in Juday Creek, Indiana. Thesis, University of Notre Dame, Notre Dame, Indiana, USA.

Lau, J. K., T. E. Lauer, and M. L. Weinman. 2006. Impacts of channelization on stream habitats and associated fish assemblages in east central Indiana. American Midland Naturalist 156:319330. http://dx.doi.org/10.1674/0003-0031(2006)156[319:IOCOSH] 2.0. $\mathrm{CO} ; 2$

Lee, D., and J. Lovell. 1998. Urban trout stream gets a second chance. Land and Water Magazine 42:16-18.

Manners, R. B., and M. W. Doyle. 2008. A mechanistic model of woody debris jam evolution and its application to wood-based restoration and management. River Research and Applications 24:1104-1123. http://dx.doi.org/10.1002/rra.1108
Marenchin, G. L., and D. M. Sever. 1981. Survey of the fishes of the St. Joseph River drainage in St. Joseph and Elkhart Counties, Indiana. Proceedings of the Indiana Academy of Science 90:454 460 .

Matheson, R. E., Jr., and G. R. Brooks, Jr. 1983. Habitat segregation between Cottus bairi and Cottus girardi: an example of complex inter- and intraspecific resource partitioning. American Midland Naturalist 110:165-176. http://dx.doi. org/10.2307/2425222

Millennium Ecosystem Assessment. 2005. Ecosystems and human well-being: synthesis. Island Press, Washington, D.C., USA.

Moerke, A. H. 2004. Landscape influences on stream ecosystems: implications for restoration and management. Dissertation. University of Notre Dame, Notre Dame, Indiana, USA.

Moerke, A. H., K. J. Gerard, J. A. Latimore, R. A. Hellenthal, and G. A. Lamberti. 2004. Restoration of an Indiana, USA, stream: bridging the gap between basic and applied lotic ecology. Journal of the North American Benthological Society 23:647-660. http://dx.doi.org/10.1899/0887-3593(2004)023<0647:ROAIUS>2.0. $\mathrm{CO} ; 2$

Moerke, A. H., and G. A. Lamberti. 2003. Responses in fish community structure to restoration of two Indiana streams. North American Journal of Fisheries Management 23:748-759. http://dx. doi.org/10.1577/M02-012

Moerke, A. H., and G. A. Lamberti. 2004. Restoring stream ecosystems: lessons from a Midwestern state. Restoration Ecology 12:327-334. http://dx.doi.org/10.1111/j.1061-2971.2004.0340.x

Moran, P. A. P. 1951. A mathematical theory of animal trapping. Biometrica 38:307-311.

Nilsson, C., R. Jansson, B. Malmqvist, and R. J. Naiman. 2007. Restoring riverine landscapes: the challenge of identifying priorities, reference states, and techniques. Ecology and Society 12(1): 16. [online] URL: http://www.ecologyandsociety.org/ vol12/iss1/art16/

O'Donnell, T. K., and D. L. Galat. 2008. Evaluating success criteria and project monitoring in river enhancement within an adaptive management framework. Environmental Management 41:90-105. http://dx.doi.org/10.1007/s00267-007-9010-5

Oksanen, J. 2011. Multivariate analysis of ecological communities. In R: Vegan tutorial. [online] URL: http://cran.rproject.org

Orzetti, L. L., R. C. Jones, and R. F. Murphy. 2010. Stream condition in Piedmont streams with restored riparian buffers in the Chesapeake Bay Watershed. Journal of the American Water Resources Association 46:473-485. http://dx.doi.org/10.1111/ j.1752-1688.2009.00414.X

Palmer, M. A. 2009. Reforming watershed restoration: science in need of application and applications in need of science. Estuaries and Coasts 32:1-17. http://dx.doi.org/10.1007/s12237-008-9129-5

Palmer, M., J. D. Allan, J. Meyer, and E. S. Bernhardt. 2007. River restoration in the twenty-first century: data and experiential knowledge to inform future efforts. Restoration Ecology 15:472481. http://dx.doi.org/10.1111/j.1526-100X.2007.00243.x 
Palmer, M. A., E. S. Bernhardt, J. D. Allan, P. S. Lake, G. Alexander, S. Brooks, J. Carr, S. Clayton, C. N. Dahm, J. Follstad Shah, D. L. Galat, S. G. Loss, P. Goodwin, D. D. Hart, B. Hassett, R. Jenkinson, G. M. Kondolf, R. Lave, J. L. Meyer, T. K. O'Donnell, L. Pagano, and E. Sudduth. 2005. Standards for ecologically successful river restoration. Journal of Applied Ecology 42:208-217. http://dx.doi.org/10.1111/j.1365-2664.2005.01004. $\underline{\mathrm{x}}$

Palmer, M. A., H. L. Menninger, and E. Bernhardt. 2010. River restoration, habitat heterogeneity and biodiversity: a failure of theory or practice? Freshwater Biology 55(Suppl. 1):205-222. http://dx.doi.org/10.1111/j.1365-2427.2009.02372.x

Paul, M. J., and J. L. Meyer. 2001. Streams in the urban landscape. Annual Review of Ecology and Systematics 32:333-365. http://dx. doi.org/10.1146/annurev.ecolsys.32.081501.114040

Peckham, R. S., and C. F. Dineen. 1957. Ecology of the central mudminnow, Umbra limi (Kirtland). American Midland Naturalist 58:222-231. http://dx.doi.org/10.2307/2422370

Poff, N. L., and J. D. Allan. 1995. Functional organization of stream fish assemblages in relation to hydrological variability. Ecology 76:606-627. http://dx.doi.org/10.2307/1941217

Pratt, A. E., and T. E. Lauer. 2013. Habitat use and separation among congeneric darter species. Transactions of the American Fisheries Society 142(2):568-577. http://dx.doi.org/10.1080/000$\underline{28487.2012 .754787}$

Reeve, T., J. Lichatowich, W. Towey, and A. Duncan. 2006. Building science and accountability into community-based restoration: can a new funding approach facilitate effective and accountable restoration? Fisheries 31:17-24. http://dx.doi. org/10.1577/1548-8446(2006)31[17:bsaaic]2.0.co;2

Rios-Touma, B., C. Prescott, S. Axtell, and G. M. Kondolf. 2014. Habitat restoration in the context of watershed prioritization: the ecological performance of urban stream restoration projects in Portland, Oregon. River Research and Applications 31:755-766. http://dx.doi.org/10.1002/rra.2769

Roni, P., K. Hanson, and T. Beechie. 2008. Global review of the physical and biological effectiveness of stream habitat rehabilitation techniques. North American Journal of Fisheries Management 28:856-890. http://dx.doi.org/10.1577/M06-169.1

Ryon, M. G. 2011. Recovery of fish communities in a warm water stream following pollution abatement. Environmental Management 47:1096-1111. http://dx.doi.org/10.1007/s00267-010-9596-X

Silliman, S. E., and D. F. Booth. 1993. Analysis of time-series measurements of sediment temperature for identification of gaining vs. losing portions of Juday Creek, Indiana. Journal of Hydrology 146:131-148. http://dx.doi.org/10.1016/0022-1694 (93) $90273-\mathrm{C}$

Silliman, S. E., J. Ramirez, and R. L. McCabe. 1995. Quantifying downflow through creek sediments using temperature time series: one-dimensional solution incorporating measured surface temperature. Journal of Hydrology 167:99-119. http://dx.doi. org/10.1016/0022-1694(94)02613-G

Simon, T. P., and R. Dufour. 1997. Development of Index of Biotic Integrity expectations for the ecoregions of Indiana: V.
Eastern Corn Belt Plain. EPA 905/R-96/002. U.S. Environmental Protection Agency, Region V, Water Division, Watershed and Nonpoint Source Branch, Chicago, Illinois, USA.

Smucker, N. J., and N. E. Detenbeck. 2014. Meta-analysis of lost ecosystem attributes in urban streams and the effectiveness of out-of-channel management practices. Restoration Ecology 22:741-748. http://dx.doi.org/10.1111/rec.12134

Society for Ecological Restoration. 2016. Washington, D.C., USA. http://www.ser.org

Stanford, J. A., J. V. Ward, W. J. Liss, C. A. Frissell, R. N. Williams, J. A. Lichatowich, and C. C. Coutant. 1996. A general protocol for restoration of regulated rivers. Regulated Rivers: Research \& Management 12:391-413. http://dx.doi.org/10.1002/(SICI)1099-1646 (199607)12:4/5<391::AID-RRR436>3.0.CO;2-4

Thompson, D. M. 2006. Did the pre-1980 use of in-stream structures improve streams? A reanalysis of historical data. Ecological Applications 16:784-796. http://dx.doi.org/10.1890/1051-0761 (2006)016[0784:DTPUOI]2.0.CO;2

Van Deventer, J. S., and W. S. Platts. 1989. Microcomputer software system for generating population statistics from electrofishing data-user's: guide for MicroFish 3.0. General Technical Report INT-254. U.S. Department of Agriculture, Forest Service, Intermountain Research Station, Ogden, Utah, USA. http://dx.doi.org/10.5962/bhl.title.100117

van Snick Gray, E., and J. R. Stauffer, Jr. 1999. Comparative microhabitat use of ecologically similar benthic fishes. Environmental Biology of Fishes 56:443-453. http://dx.doi. org/10.1023/A:1007536019444

Violin, C. R., P. Cada, E. B. Sudduth, B. A. Hassett, D. L. Penrose, and E. S. Bernhardt. 2011. Effects of urbanization and urban stream restoration on the physical and biological structure of stream ecosystems. Ecological Applications 21:1932-1949. http:// dx.doi.org/10.1890/10-1551.1

Walsh, C. J., A. H. Roy, J. W. Feminella, P. D. Cottingham, P. M. Groffman, and R. P. Morgan, II. 2005. The urban stream syndrome: current knowledge and the search for a cure. Journal of the North American Benthological Society 24:706-723. http:// dx.doi.org/10.1899/04-028.1

Warren, D. N., and C. E. Kraft. 2003. Brook trout (Salvelinus fontinalis) response to wood removal from high-gradient streams of the Adirondack Mountains (N.Y., U.S.A.). Canadian Journal of Fisheries and Aquatic Sciences 60:379-389. http://dx.doi. org/10.1139/f03-031

Wissmar, R. C., and R. L. Beschta. 1998. Restoration and management of riparian ecosystems: a catchment perspective. Freshwater Biology 40:571-585. http://dx.doi.org/10.1046/ j.1365-2427.1998.00383.x

Wohl, E., P. L. Angermeier, B. Bledsoe, G. M. Kondolf, L. MacDonnell, D. M. Merritt, M. A. Palmer, N. L. Poff, and D. Tarboton. 2005. River restoration. Water Resources Research 41, W10301. http://dx.doi.org/10.1029/2005wr003985

Zimmerman, J. K. H., and B. Vondracek. 2007. Interactions between slimy sculpin and trout: slimy sculpin growth and diet in relation to native and nonnative trout. Transactions of the 
American Fisheries Society 136:1791-1800. http://dx.doi. org/10.1577/T06-020.1

Zippin, C. 1956. An evaluation of the removal method of estimating animal populations. Biometrics 12:163-189. http://dx. doi.org/10.2307/3001759

Zippin, C. 1958. The removal method of population estimation. Journal of Wildlife Management 22:82-90. http://dx.doi. org/10.2307/3797301 
Long-term fish community response to a reach-scale stream restoration. Ecology and Society.

Appendix 1. This appendix is a detailed acknowledgement of those individuals who dedicated their time to make possible the scientific study of the Juday Creek restoration at Notre Dame's Warren Golf Course, particularly the monitoring of the fish assemblage. We thank them for their time to help make publication of this manuscript possible.

One of our helpers, a creative writer by the name of L. Scott Parkinson, wrote this poem after helping us sample Juday Creek:

"Ode to the creek chub"

oh, rotund silvered rose of the waters

you bring beauty to the bleak benthos

reflecting the muted sunlight

you are a beacon for the leviathans

to follow in the tannin darkened currents.

within your shadowed kingdom you reign exquisitely over the browns and steelheads the fat lipped suckers and the lovely darters the young of year largemouths and bluegills grand beasts bend their scaled heads to your kind and just supremacy.

it is said that on moonlit evenings when the orange and yellow leaves begin their downward journeys from life to death that you, lovely monarch of the creek, may be seen riding a monstrous and ancient snapping turtle surveying your peaceful realm. the distant stars reveal their pure white light in your perfect and mirrored body. even the heavens love you.

L.S. Parkinson 2011 
Long-term fish community response to a reach-scale stream restoration. Ecology and Society.

We thank our field assistants in alphabetical order (year of assistance in parentheses):

Patricia (Trixie) Amorado (2011),

Ashley Baldridge $(2009,2011)$,

Matthew Barnes (2006),

Candice (Goy) Bauer (1998),

Randy Bernot (2003-2004),

Nicole (Mitchell) Blair (1999),

Leah Boits (2005),

Leanne Brady (2000),

Elizabeth Brueseke (2005, 2008, 2010, 2012),

Rebecca Buck (2005),

Anthony Cak (2001),

Dominic Chaloner (2003-2005, 2007-2008),

Bryan Cole (2001),

Matthew Cooper (2010, 2012),

David Costello (2004-2009),

Angela (Bobeldyk) Deen (2004-2007),

Sam Deery-Schmitt (2013),

Andrew Deines (2006),

Sally Entrekin (2003-2007),

Nathan Evans (2010-2011),

Dayna (Smith) Evans (2012-2013),

Michelle Evans-White (2000, 2004),

Charlotte Flora (2006),

Andrea Fowler (2005, 2007),

Therese Frauendorf (2007),

Kelly Garvy (2009),

Alex Gatlin (2009),

Kacey Gergely (2010),

Brandon Gerig (2013),

Lindsay Goodwin (2000),

Amy Govert-Larson (2005),

Julia Hart (2013),

Jamie Hebbeler (2006),

Suse Hebbeler (2006),

Kelly Heilman (2013),

Brad Herrick (1999),

Katrina Hochstein-Mueller (2002),

Timothy Hoellein $(2003,2007)$,

Mary Hupka (2013),

Wendy Hurley (2005),

David Janetski (2006-2007, 2010),

Tessa Johnson (1998), 
Jessica Kenzie (1998),

Jason Knouft (2001),

Jessica Kosiara (2011-2013),

Edward (Ted) Kratschmer (2008-2009),

Konrad Kulacki (2003-2008),

Brianna Kunycky (2009),

James Larson (2004-2006),

Jennifer Lozano (2009),

Michael McDonough (2000),

Vanessa (Nero) McDonough (2000),

Jack McLaren (2012),

Ashley Moerke (1997-2003),

Kerry (Gerard) Muldoon (2000),

Jen Nelson (1998),

Haley Pack (2012),

L. Scott Parkinson (2009-2010),

Christopher Patrick (2007, 2009),

Brett Peters (2005-2007),

Jody (Murray) Peters (2005, 2007),

Ira Poplar-Jeffers (2002),

Brett Olds (2013),

Mark Renshaw (2013),

Sarah Roley (2010),

Janine Rüegg (2009),

Melanie Runkle (2013),

Sister Damien Marie Savino (2006),

Megan Schlichte (2008),

Sheina Sim (2008),

Maggie Sinclair (1999),

Amy (Noel) Smith (2001),

Ryan Stubbs (1998),

Shayna Sura (2009),

Mary Swanson (2011),

Shannon Torrence (1999),

Cameron Turner (2013),

Karen Uly (2013),

John Valainis (1999),

Liza Cosca Villaruz (2000),

Carmella Vizza (2013),

Andrew Wilson (2013),

Sarah (Winnie) Winikoff (2011),

Sunil K. Yadav (2011), and

Asako Yamamuro (2001). 

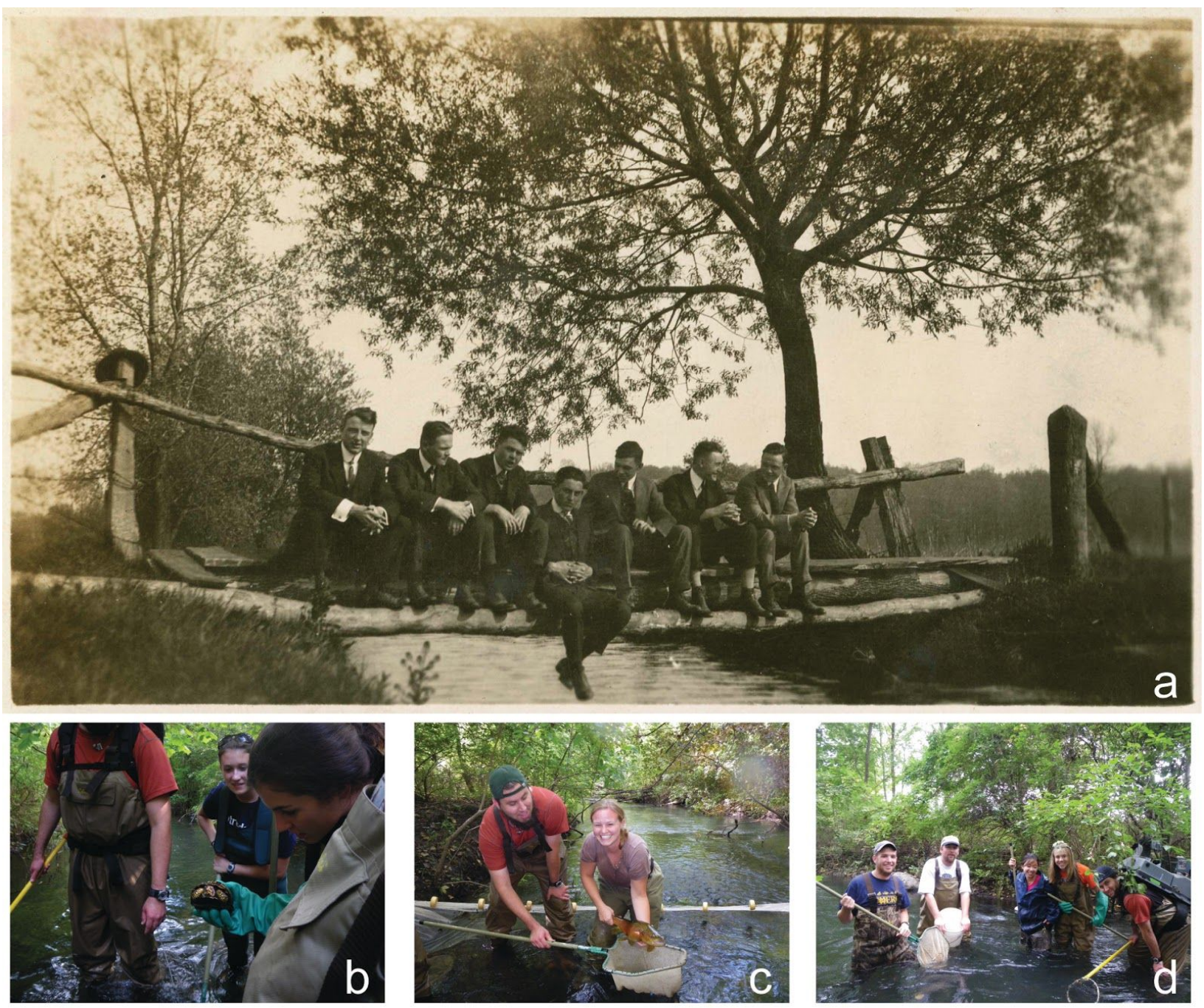

Figure A1.1. Juday Creek has been used to educate students from elementary school to college-age adults as part of curricula where participants learn what organisms live in the stream; this tradition dates to the 1860s at the University of Notre Dame. Top photograph (a) shows the earliest known photograph of Juday Creek near the campus circa 1910, courtesy of the University of Notre Dame Archives. Bottom photographs show (b) undergraduate students (Brianna Kunycky and Kelly Garvy) examining an eastern box turtle Terrapene carolina, which is a protected species in Indiana (2009); (c) a student (Shayna Sura) holding a non-native brown trout Salmo trutta (2009); and (d) undergraduate and graduate students (from left: Ted Kratschmer, Konrad Kulacki, Sheina Sim, and Megan Schlicte) helping with electrofishing (2008). 


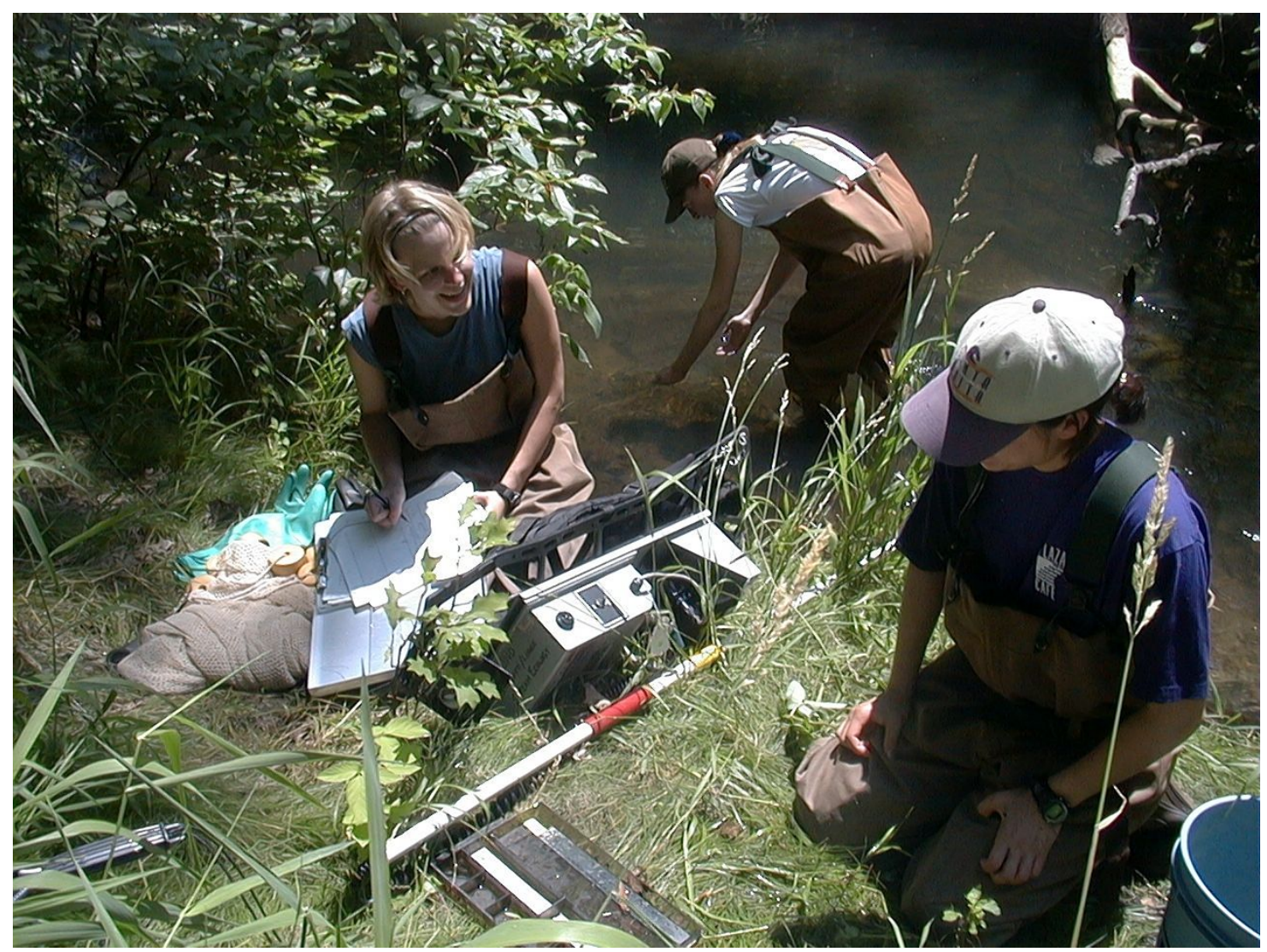

Figure A1.2. Electrofishing crew processing fish on June 26, 2001 with Ashley Moerke taking notes, Amy (Noel) Smith releasing a fish and Asako Yamamuro ready to measure another fish in foreground. 

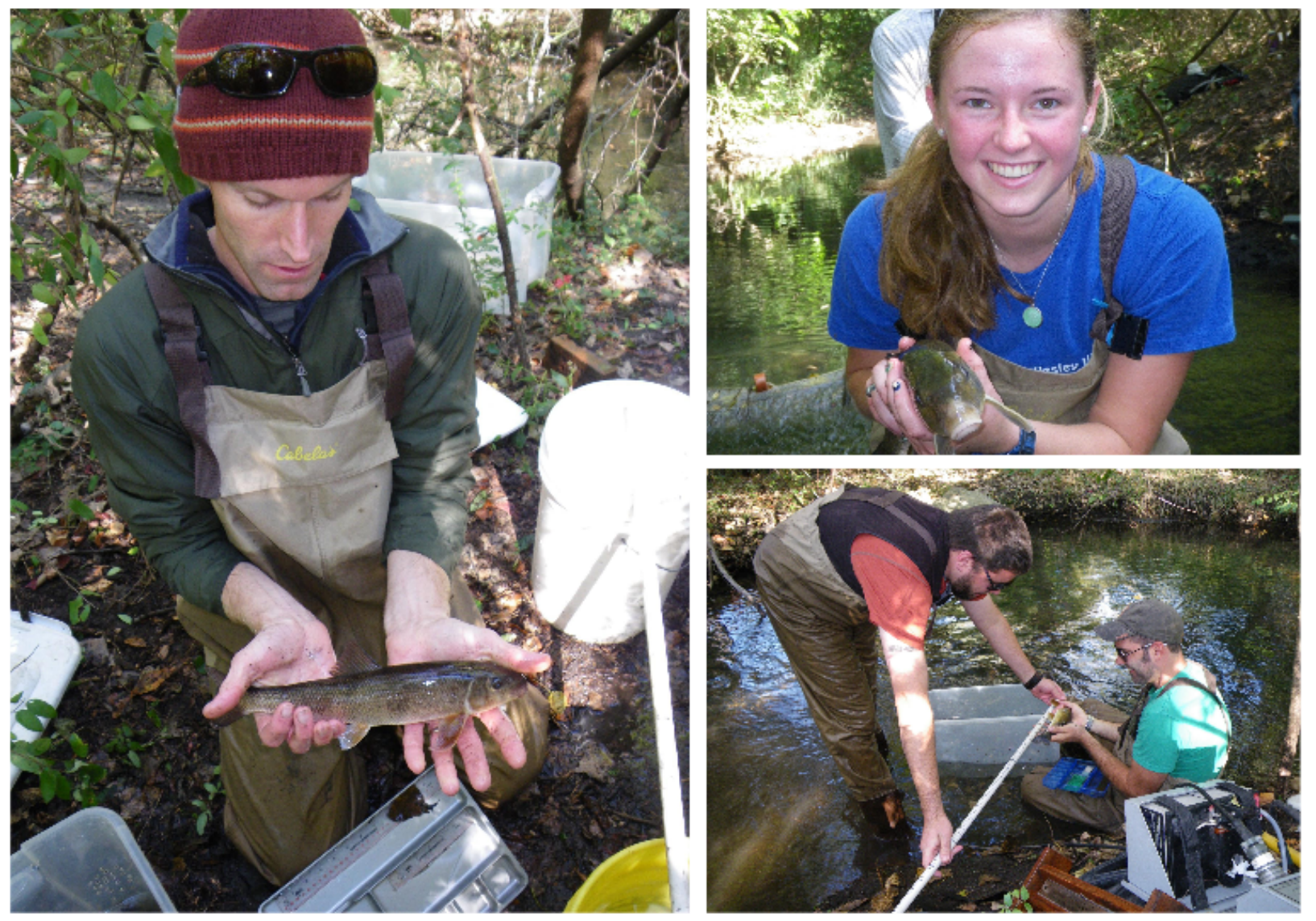

Figure A1.3. Photographs of individuals helping measure white sucker. Clockwise from left: Matthew Cooper on Oct. 5, 2010, Melanie Runkle on Sep. 11, 2013, and L. Scott Parkinson helping Michael Brueseke on Oct. 8, 2010. Sucker were a component of the diet of the native Potawatomi and Miami Peoples, the previous caretakers of watersheds like Juday Creek. 
Long-term fish community response to a reach-scale stream restoration. Ecology and Society.

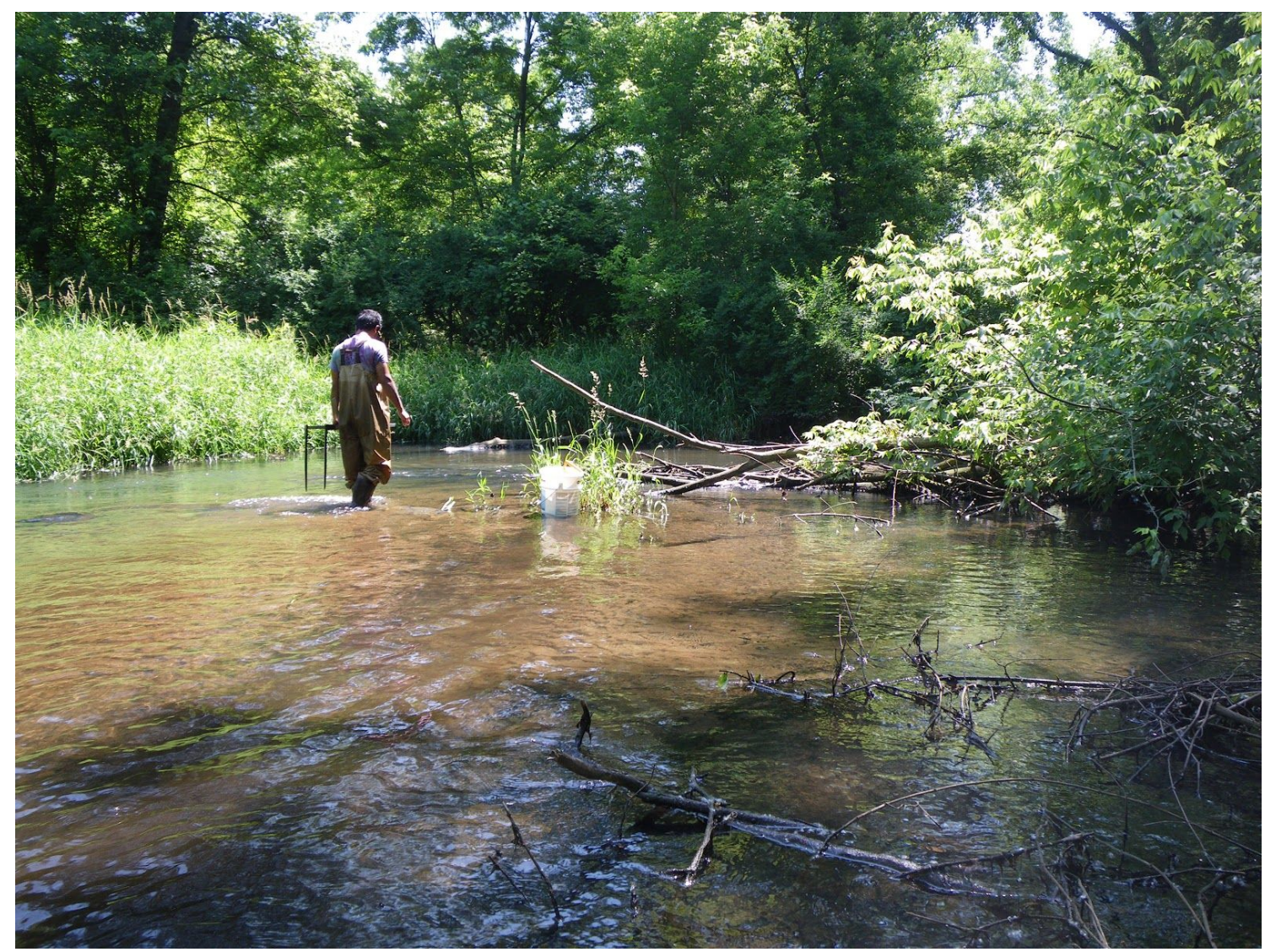

Figure A1.4. Photograph showing Sunil K. Yadav helping to measure large woody debris on June $17,2011$. 
Long-term fish community response to a reach-scale stream restoration. Ecology and Society.

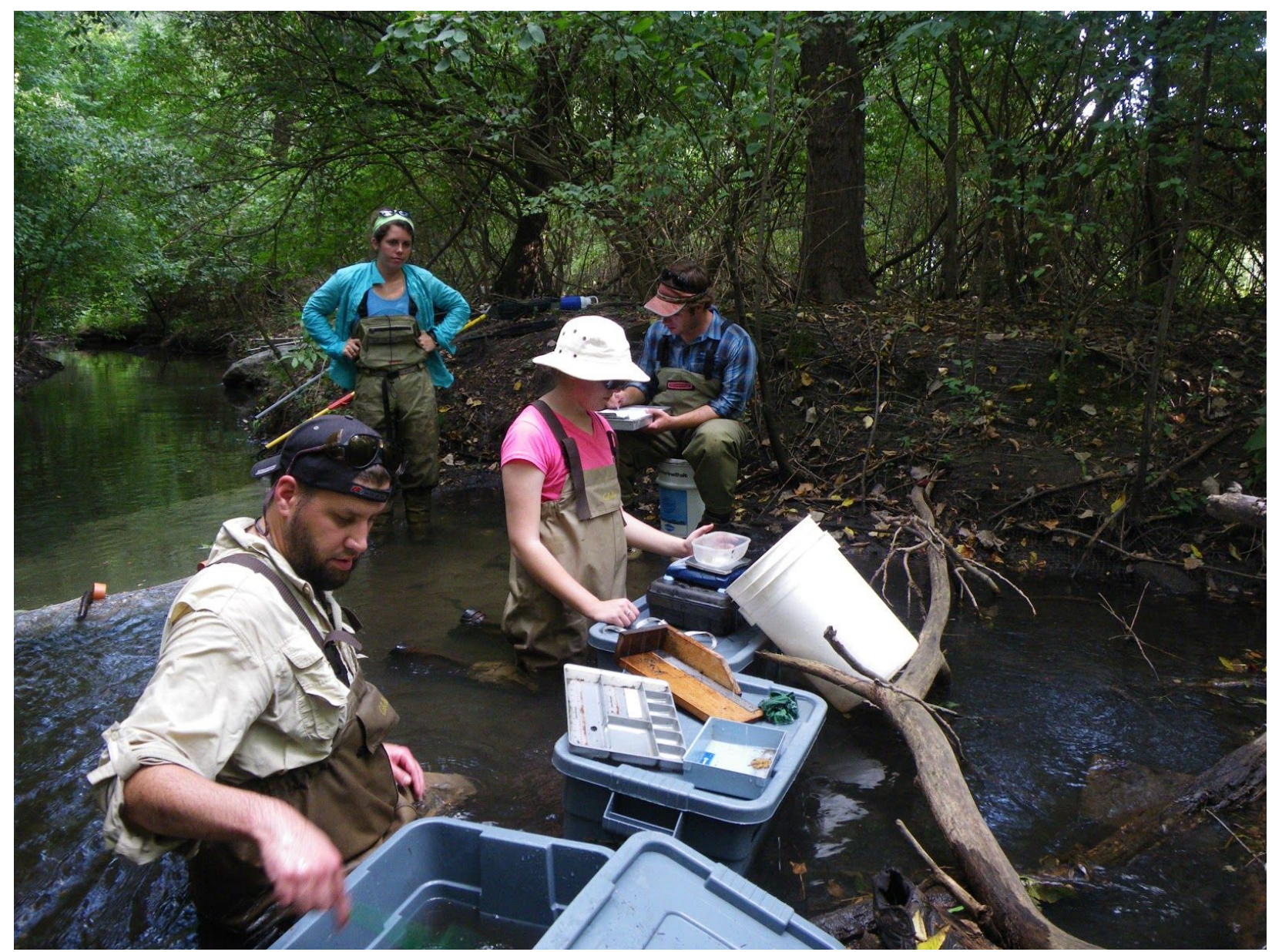

Figure A1.5. Kelly Heilman, Dayna (Smith) Evans, and Brandon Gerig helping Michael Brueseke measure fish on Sep. 11, 2013. 


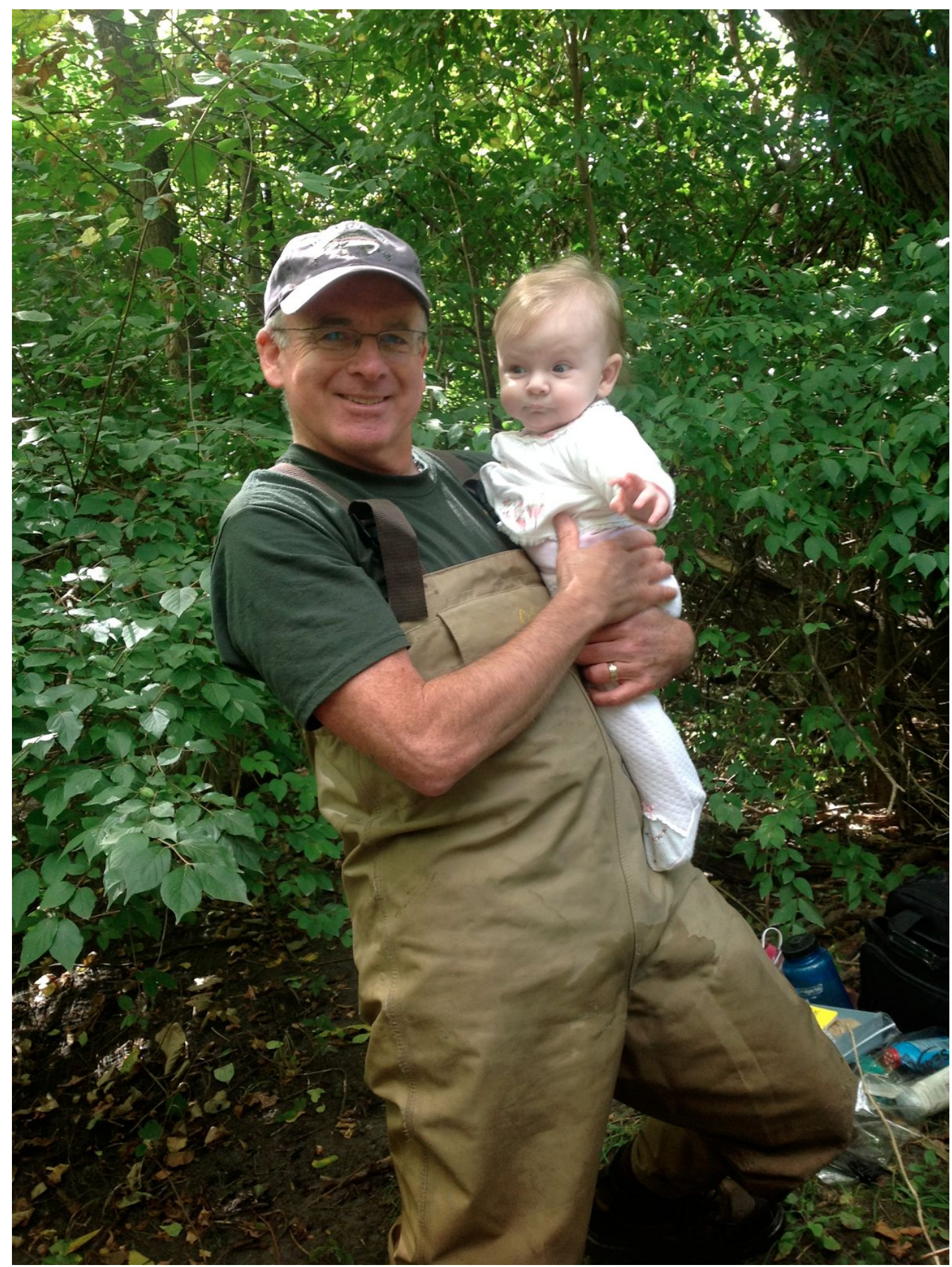

Figure A1.6. Even the youngest of crew members sacrificed their time to help the sampling effort, as 6-month-old Maria Shirey is held by Gary Lamberti on September 13, 2013 after a few hours of supervising fieldwork streamside. 